NBER WORKING PAPER SERIES

\title{
ESTIMATING THE SOCIAL RETURN TO HIGHER EDUCATION: EVIDENCE FROM LONGITUDINAL AND REPEATED CROSS-SECTIONAL DATA
}

\author{
Enrico Moretti \\ Working Paper 9108 \\ http://www.nber.org/papers/w9108 \\ NATIONAL BUREAU OF ECONOMIC RESEARCH \\ 1050 Massachusetts Avenue \\ Cambridge, MA 02138 \\ August 2002
}

"Previous versions of this paper appeared as Center for Labor Economics Working Papers in 1998 and 1999". I am deeply indebted to David Card for many helpful conversations and insightful advice. I also thank Joshua Angrist, John Bound, Ken Chay, David Levine, Michael Greenstone, Darren Lubotsky, Marco Manacorda, Jeff Perloff, three anonymous referees and the participants in the seminars at Berkeley, MIT, Chicago, Yale, UCLA, Toronto, Brown, LSE, UCL, Tilburg, Santa Barbara, Irvine for many useful suggestions on this and an earlier draft. All errors are naturally my own. Financial support from the A. P. Sloan Dissertation Scholarship is gratefully acknowledged. The views expressed herein are those of the author and not necessarily those of the National Bureau of Economic Research.

(C) 2002 by Enrico Moretti. All rights reserved. Short sections of text, not to exceed two paragraphs, may be quoted without explicit permission provided that full credit, including (C) notice, is given to the source. 
Estimating the Social Return to Higher Education: Evidence From

Longitudinal and Repeated Cross-Sectional Data

Enrico Moretti

NBER Working Paper No. 9108

August 2002

JEL No. J3, I2

\begin{abstract}
Economists have speculated for at least a century that the social return to education may exceed the private return. In this paper, I estimate spillovers from college education by comparing wages for otherwise similar individuals who work in cities with different shares of college graduates in the labor force. OLS estimates show a large positive relationship between the share of college graduates in a city and individual wages, over and above the private return to education. A key issue in this comparison is the presence of unobservable individual characteristics, such as ability, that may raise wages and be correlated with college share. I use a confidential version of the National Longitudinal Survey of Youth (NLSY) to estimate a model of non-random selection of workers among cities. By observing the same individual over time, I can control for differences in unobserved ability across individuals and differences in the return to skills across cities. I then investigate the hypothesis that the correlation between college share and wages is due to unobservable city-specific shocks that may raise wages and attract more highly educated workers to different cities. To control for this source of potential bias, I turn to Census data and use two instrumental variables: the lagged city demographic structure and the presence of a land--grant college. The results from Census data are remarkably consistent with those based on the NLSY sample. A percentage point increase in the supply of college graduates raises high school drop-outs' wages by $1.9 \%$, high school graduates' wages by $1.6 \%$, and college graduates wages by $0.4 \%$. The effect is larger for less educated groups, as predicted by a conventional demand and supply model. But even for college graduates, an increase in the supply of college graduates increases wages, as predicted by a model that includes conventional demand and supply factors as well as spillovers.
\end{abstract}

\author{
Enrico Moretti \\ Department of Economics \\ UCLA \\ 405 Hilgard Avenue \\ Los Angeles, CA 90095-1477 \\ and NBER \\ moretti@ucla.edu
}




\section{Introduction}

Economists have speculated for at least a century that the social return to education may exceed the private return. Different explanations have been offered for such spillovers. For example, the sharing of knowledge and skills through formal and informal interaction may generate positive externalities across workers. ${ }^{1}$ Alternatively, spillovers from education may arise through search externalities or endogenous skill-biased technical change. ${ }^{2}$ Some have hypothesized that education may have economic and non-economic benefits in addition to its effect on earnings. ${ }^{3}$

State and local governments subsidize primary and secondary education. Almost all direct operating costs are completely subsidized through high school. The current subsidy of direct costs to students at major public universities in the U.S. is around $80 \%$ (Heckman 2000). The magnitude of the social return to education is important for assessing the efficiency of public investment in education. Despite the significant policy implications and a large theoretical literature that assumes the existence of spillovers from education, the empirical evidence on the magnitude of any spillovers is limited. ${ }^{4}$

In this paper, I test the hypothesis that the economic returns to college are fully reflected in the earnings of college educated workers against the alternative theory that other individuals in the same labor market benefit from spillovers associated with higher overall levels of education. I focus on local labor markets and identify the social return to higher education by comparing the wages of otherwise similar individuals living in metropolitan areas with different shares of college educated workers in the labor force. OLS estimates show a large positive relationship between individual wages and the share of college grad-

\footnotetext{
${ }^{1}$ See for example Marshall (1890), Lucas (1988), Jovanovic and Rob (1989).

${ }^{2}$ See Acemoglu (1996) and Acemoglu (1998).

${ }^{3}$ Milton Friedman (1962) argued for public subsidies to education on the grounds that a better-educated electorate makes better decisions over policy choices that affect the economy.

${ }^{4}$ The only studies that adopt an approach similar to the one used here are Rauch (1993) and Acemoglu and Angrist (2000), and are discussed in detail below. Topel (1999) and Krueger and Lindahl (1998) estimate the social return to education using cross-country data. Borjas (1995) shows that economic success of children of immigrants depends not only on parental inputs, but also on the average human capital of the relevant ethnic group. Sacerdote (2000), Zimmerman (2002) and Stinebrickner and Stinebrickner (1999) investigate the magnitude of peer effects among college students. Findings are mixed. Glaeser, Scheinkman and Shleifer (1995) report that income per capita has grown faster in cities with high initial human capital in the post-war period.
} 
uates in a city, even after controlling for the direct effect of individual education on wages. However, it is not clear whether this documented association is causal.

A fundamental issue in the interpretation of this simple specification is the presence of unobservable factors that are correlated with college share and wages across cities. First, there may be unobserved individual characteristics, such as ability, that are correlated both with wages and college share across cities. It is plausible that workers with high levels of unobserved ability sort into cities with well-educated labor forces. This type of sorting could take place if a larger college share in a city is associated with a higher return to unobserved ability, causing higher quality workers to move to cities with larger college shares. In this case, the correlation between wages and college share might simply reflect differences in unobserved workers ability rather than differences in productivity.

To control for this potential source of bias, I use longitudinal data from the National Longitudinal Survey of Youths (NLSY) and estimate a model of non-random selection of workers among cities. By observing the same individual over time, I can control for individual and city fixed effects. I find that omitted individual characteristics are not a major source of bias.

A second potential source of bias is city-specific unobserved characteristics that are correlated with college share. Cities differ widely in geographical location, industrial structure, weather and amenities. Cities where the productivity of skilled workers is particularly high-because of unobserved differences in industrial mix, technology or natural resources - pay higher wages and therefore attract more skilled workers. The computer industry boom, for example, has raised wages of skilled workers and therefore attracted a very skilled labor force to Silicon Valley. In this case, high wages cause the number of college graduates in the city to rise, not vice-versa.

To abstract from city-level unobserved heterogeneity, I turn to the 1970, 1980 and 1990 Censuses and implement two different estimation strategies. First, I control directly for estimated city-specific productivity shocks in the wage regressions. To estimate these shocks I use a measure of demand shifts proposed by Katz and Murphy (1992). 
Second, I use instrumental variables. What is needed is an instrument that is correlated with college share in a city and uncorrelated with unobserved factors that affect wages directly. I consider two alternatives. The first is based on differences in the age structure of cities. The U.S. labor force is characterized by a long-run trend of increasing education, with younger cohorts better-educated than older ones. To lessen any fear that age structure is endogenous, I use the 1970 age structure to predict changes in college share between 1980 and 1990. The second instrument, which can be used only in cross-sectional models, is an indicator for the presence of a land-grant college in the city. Land-grant colleges were established by the federal Morrill Act of 1862. Because the program was federal and took place more than one hundred years ago, the presence of a land-grant institution is unlikely to be correlated with local labor market conditions in the 1980s.

The results from the Census data are remarkably consistent with those from the NLSY. I find that a 1 percentage point increase in college share in a city raises average wages by $0.6 \%-1.2 \%$, above and beyond the private return to education. Of course finding that average wages are affected by the percentage of college graduates in the labor force does not necessarily indicate a spillover effect: rather this finding may indicate imperfect substitution between high and low education workers. For this reason, I estimate the effect of changes in the fraction of highly educated workers on wages of different education groups. By comparing the effect of an increase in the share of college graduates across education groups, I hope to shed some light on the size of the spillover. Standard demand and supply considerations suggest that the effect of an increase in college share should be positive for low education groups and that for college graduates its sign should depend on the size of the spillover. I find that a 1 percentage point increase in the labor force share of college graduates increases the wages of high-school drop-outs and high-school graduates by $1.9 \%$ and $1.6 \%$, respectively. It also increases wages of college graduates by $0.4 \%$. Consistent with a model that includes both conventional demand and supply factors and spillovers, a rise in the portion of better-educated workers has a large positive effect on less-educated workers, but also generates a smaller rise in wages for the best-educated group. 
The remainder of this paper is organized as follows. The next section provides a simple theoretical framework. Section 3 describes the empirical identification strategy. Section 4 reports results from a panel data model estimated with NLSY data. In this model all education groups are pooled together. In Section 5, a more general model is estimated with Census data, where the effect of college share varies by education group. Robustness checks are presented in Section 6. Section 7 compares results with the existing literature. Section 8 concludes.

\section{Theoretical Framework}

The main goal of this paper is to estimate the social return to education. The social return is the sum of the private return and the external return. Similarly to Acemoglu and Angrist (2000), I define the external return to education as the effect of an increase in the share of educated workers in a city on total wages minus the effect due to private returns to education. An increase in the share of educated workers may increase total wages over and above the private return to education for two separate reasons. First, the standard neoclassical model suggests that if educated and uneducated workers are imperfect substitutes, an increase in the share of educated workers will raise productivity of uneducated workers. (Empirical evidence confirms that educated and uneducated workers are imperfect substitutes; see Katz and Murphy, 1992 and Freeman, 1986.) Second, there may be human capital spillovers.

In this section I begin by presenting a simple theoretical model that includes both standard demand and supply factors and spillovers from education. The model identifies the effect of an increase in the relative supply of educated workers in a city on wages for different education groups. Standard demand and supply considerations suggest that wages of uneducated workers benefit both from imperfect substitution and the spillover, while the wages of educated workers suffer from the increased supply of educated workers but benefit from the spillover. In section 2.2 I present a simple general equilibrium model 
to show that, in equilibrium, spillovers can be identified.

\subsection{Spillovers vs Imperfect Substitution}

To understand the effect of changes in the share of college educated workers in a city on wages, it is convenient to treat each city as a competitive economy that produces a single output good $y$ traded on the national market. Assume that there is a Cobb-Douglas technology that employs skilled and unskilled workers and capital:

$$
y=\left(\theta_{1} N_{1}\right)^{\alpha_{1}}\left(\theta_{2} N_{2}\right)^{\alpha_{2}} K^{1-\alpha_{1}-\alpha_{2}}
$$

where $N_{1}$ is the number of workers with high education in the city; $N_{2}$ is the number of workers with low education; $\mathrm{K}$ is capital; and the $\theta$ 's are productivity shifters. The Cobb-Douglas technology is chosen only for its simplicity. Results do not change if a more general CES technology is used.

I allow for human capital spillovers by letting workers' productivity depend on the share of educated workers in the city, as well as on their own human capital:

$$
\log \left(\theta_{j}\right)=\phi_{j}+\gamma\left(\frac{N_{1}}{N_{1}+N_{2}}\right) \quad j=1,2
$$

where $\phi_{j}$ is a group-specific effect that captures the direct effect of own human capital on productivity $\left(\phi_{1}>\phi_{2}\right) ; \frac{N_{1}}{N_{1}+N_{2}}$ is share of college educated workers in the city. If $\gamma=0$, the model is the standard Mincerian model of wage determination without spillovers. If there are positive spillovers, $\gamma>0$. In the literature, there exist different types of models of human capital spillovers. ${ }^{5}$ The empirical specification adopted in this paper is consistent

\footnotetext{
${ }^{5}$ The idea of human capital spillovers is old in economics. Marshall (1890) is often quoted as arguing that social interactions among workers in the same industry and location create learning opportunities that enhance productivity. More recent literature has built on Marshall's insight by assuming that human capital externalities arise because workers learn from each other, and they learn more from more skilled individuals. An influential paper by Lucas (1988) suggests that human capital spillovers may help explaining differences in long run economic performance of countries. The sharing of knowledge and skills through formal and informal interaction is viewed as the mechanism that generates positive spillovers across workers. More recent models build on this idea by assuming that individuals augment their human capital through pairwise meetings with more skilled neighbors at which they exchange ideas (Glaeser 1997, Jovanovic and Rob 1989). Other authors focus on the importance of basic research in fostering technological innovation and productivity, the public good nature of the research and the resulting positive externalities in the form of knowledge spillovers (see, for example, Arrow (1962), Griliches (1979)).
} 
with most types of human capital spillovers. Distinguishing between alternative sources of spillovers, although important for policy implications, is beyond the scope of this paper.

If wages are equal to the marginal product of each type of labor and the spillover is external to individual firms in the city but internal to the city as a whole (so that firms take the $\theta$ 's as given), the logarithm of wages for educated and uneducated workers respectively are: $\log \left(w_{1}\right)=\log \left(\alpha_{1}\right)+\left(\alpha_{1}-1\right) \log \left(N_{1}\right)+\alpha_{1} \log \left(\theta_{1}\right)+\alpha_{2} \log \left(\theta_{2} N_{2}\right)+\left(1-\alpha_{1}-\alpha_{2}\right) \log (K)$ and $\log \left(w_{2}\right)=\log \left(\alpha_{2}\right)+\alpha_{1} \log \left(\theta_{1} N_{1}\right)+\left(\alpha_{2}-1\right) \log \left(N_{2}\right)+\alpha_{2} \log \left(\theta_{2}\right)+\left(1-\alpha_{1}-\alpha_{2}\right) \log (K)$. Consider what happens to the wages when the share of high education workers increases in the city: ${ }^{6}$

$$
\begin{aligned}
& \frac{d \log \left(w_{2}\right)}{d N_{1}}=\alpha_{1} \frac{1}{N_{1}}+\gamma\left[\frac{\left(\alpha_{1}+\alpha_{2}\right)(1-s)}{N_{1}+N_{2}}\right] \\
& \frac{d \log \left(w_{1}\right)}{d N_{1}}=-\left(1-\alpha_{1}\right) \frac{1}{N_{1}}+\gamma\left[\frac{\left(\alpha_{1}+\alpha_{2}\right)(1-s)}{N_{1}+N_{2}}\right]
\end{aligned}
$$

where $s=\frac{N_{1}}{N_{1}+N_{2}}<1$. The wage of uneducated workers, $w_{2}$, benefits for two reasons. First, an increase in the number of educated workers raises uneducated workers' productivity because of imperfect substitution: $\alpha_{1} \frac{1}{N_{1}}>0$. Second, the spillover further raises their productivity: $\gamma\left[\frac{\left(\alpha_{1}+\alpha_{2}\right)(1-s)}{\left(N_{1}+N_{2}\right)}\right]>0$. The impact of an increase in the supply of educated workers on their own wage, $w_{1}$, is determined by two competing forces: the first is the conventional supply effect which makes the economy move along a downward sloping demand curve: $-\left(1-\alpha_{1}\right) \frac{1}{N_{1}}<0$. The second is the spillover that raises productivity. The important feature of equations 3 and 4 is that unskilled workers benefit from an increase in the share of educated workers in the city even in the absence of any spillovers $(\gamma=0)$, but the effect on the wage of skilled workers depends on the magnitude of the spillover. If $\gamma$ is large enough, $\gamma>\left(1-\alpha_{1}\right) /\left[\left(\alpha_{1}+\alpha_{2}\right) s(1-s)\right]$, the net effect for skilled workers should be positive although smaller than for unskilled workers. If $\gamma=0$, the net effect should be

\footnotetext{
Finally, human capital spillovers may arise if human and physical capital are complements even in the absence of learning or technological externalities (Acemoglu 1996).

${ }^{6}$ Here I am looking at the effect of an increase in the number of educated workers holding the number of uneducated workers constant. Results are similar when looking at the effect of an increase in the number of educated workers holding constant the total number of workers in the city.
} 
negative.

Following Acemoglu and Angrist (2000), I define the external return to education as the derivative of total wage income with respect to $N_{1}$ minus the private return:

$$
\frac{d \log (\bar{w})}{d N_{1}}-\beta
$$

where $\log (\bar{w})$ is the weighted sum of log wages of the two groups, $\log (\bar{w})=N_{1} \log \left(w_{1}\right)+$ $N_{2} \log \left(w_{2}\right) ; \beta$ is the private return, defined as the difference between the wage of educated and uneducated workers $\beta=\log \left(w_{1}\right)-\log \left(w_{2}\right)$. It is easy to show that the external return to education is the sum of three components:

$$
\frac{d \log (\bar{w})}{d N_{1}}-\beta=N_{1} \frac{d \log (\beta)}{d N_{1}}+\frac{d \log \left(w_{2}\right)}{d N_{1}}+\gamma
$$

The first component is the effect of an increase of educated workers on the private return to education. This effect is negative, because as the supply of educated workers in a city increases, the private return decreases. The second effect captures the imperfect substitution between educated and uneducated workers, and is positive. The third effect reflects the spillover. The sum of the first two components is positive, because the increase in productivity for low education workers more than offsets the effect of the decrease in the private return to education. ${ }^{7}$ Therefore, a rise in the number of educated workers in a city increases the average wage even in the absence of any spillovers $(\gamma=0)$.

In the empirical part of the paper, I first estimate the overall external return to education (Sections 4). In view of the framework presented in this Section, I then separately estimate the effect of the share of college graduates on the wages of different education groups (Section 5). By comparing the effect of an increase in the share of college graduates across education groups, I hope to shed some light on the size of the spillover. The model predicts that the net effect should be positive for low education groups and that for college

\footnotetext{
${ }^{7}$ This is true for any CES technology, unless the elasticity of substitution is infinite. For a proof see Acemoglu and Angrist 1999, Appendix A2.
} 
graduates its sign should depend on the size of the spillover. Policy implications depend on whether the external return arises exclusively from imperfect substitution or also partially reflects spillovers. The standard imperfect substitution effect is not itself a market failure. However, if human capital spillovers exist, a market failure may arise.

\subsection{General Equilibrium}

I now turn to a general equilibrium framework proposed by Roback $(1982,1988)$ to show that an equilibrium exists when externalities are present. Roback's framework is often used to model worker and firm location decisions, with or without externalities (Rauch 1993, Beeson and Eberts 1989, Blomquist, Berger and Hoehn 1988). A second goal of this section is to identify sources of bias of the OLS estimator.

I retain the assumptions made in Section 2.1. I also assume that there are two types of goods, a composite good $y$ —nationally traded - and land $h$-locally traded. Workers maximize utility subject to a budget constraint by choosing quantities of the composite good and residential land, given the city amenity, $v^{\prime}$. Workers and firms are perfectly mobile. Equilibrium is obtained when workers have equal utilities in all cities and firms have equal unit cost across cities. Because the composite good, $y$, is traded, its price is the same everywhere and set to 1 . Variation in the cost of living depends only on variation in cost of land, $p$, which is assumed to be the same for all workers in the same city, irrespective of the education group. The good $y$ is produced according to equation 1 , but I ignore capital for simplicity. Land is not produced.

The equilibrium for the simple case of only two cities, A and B, is described in Figure 1. The upward sloping lines in each panel represent indifference curves for the two education groups. Indirect utility of workers belonging to group $j, V_{j}\left(w_{j}, p, v^{\prime}\right)$, is a function of the group's nominal wage, $w_{j}$, cost of land and the amenity. The indifference curves are upward sloping because workers prefer higher wages and lower rent. Since workers are free to migrate, utility of workers is equalized across locations: $V_{1}\left(w_{1}, p, v^{\prime}\right)=k_{1}$ and $V_{0}\left(w_{0}, p, v^{\prime}\right)=k_{0}$ for educated and uneducated workers, respectively. The downward slop- 
ing lines show combinations of wages and rents which hold constant firms' unit costs: $C_{c}\left(w_{0}, w_{1}, p\right)=1$, where $w_{0}$ and $w_{1}$ are wages of uneducated and educated workers, respectively; and $c$ indexes city. (If production functions vary across cities, for example because of spillover effects, then the unit cost functions are city-specific.) A zero-profit condition for the firm assures that production must take place along the downward sloping curve. Thus the model has three equations (unit cost and indirect utility for each skill group) in three unknowns $\left(w_{0}, w_{1}\right.$ and $\left.p\right)$. Point 1 in the left panel of Figure 1 represents the equilibrium combination of wage of educated workers and cost of land in city A. Point 1 in the right panel represents the same combination for uneducated workers. Rent is the same for both skill groups.

If the two cities are identical, the equilibrium in city $\mathrm{B}$ is the same. There are two ways to make the share of educated workers higher in city B than in city A, either by increasing the relative supply or the relative demand of educated workers in B. I begin by considering what happens to equilibrium wages when the relative supply of educated workers is higher in B than in A. Later I consider what happens to equilibrium wages when the relative demand of educated workers is higher in B than in A. One way of making the relative supply of educated workers higher in B than in A is to assume that city B has an higher level of the local amenity than city $\mathrm{A}\left(v_{B}^{\prime}>v_{A}^{\prime}\right)$ and educated workers value the amenity, while uneducated workers don't. I interpret $v^{\prime}$ broadly, as any exogenous factor that increases the relative supply of educated workers.

The indifference curve at level $k_{1}$ of educated workers in city $\mathrm{B}$ is to the left of the corresponding curve in A, while the indifference curve for uneducated workers does not change. If there are no spillovers, the increase in the supply of educated workers in city $\mathrm{B}$ raises the wage of uneducated workers to $w_{0}^{\prime}$ and lowers the wage of educated ones to $w_{1}^{\prime}$ (point 2 in both panels of Figure 1). This is the standard result. Because of complementarity, uneducated workers are now more productive in city B. Because of the amenity, educated workers accept lower wages there.

If there are spillovers, however, the combinations of wages and rents that hold firms' 
costs constant in city $\mathrm{B}$ is to the right of the corresponding combination in city A for both groups (point 3). For educated workers, the shift of the isocost curve is caused by the spillover only; for uneducated workers the shift is caused by both complementarity (movement from 1 to 2 ) and the spillover (movement from 2 to 3 ). The important feature of the equilibrium is that complementarity and spillover both increase wages of uneducated workers, while the impact of an increase in the supply of educated workers on their own wage is determined by two competing forces: the first is the conventional supply effect which makes the economy move along a downward sloping demand curve; the second is the spillover that raises productivity. If the spillover is strong enough, as in Figure 1, the equilibrium wage of educated workers in city B is higher than in city A. ${ }^{8}$

So far I have considered the case where differences in the relative number of educated workers are driven by differences in the relative supply. I now turn to the case where the case where differences in the relative number of educated workers are driven by differences in the relative demand. In Figure 2 cities are identical in term of amenities, but differ in term of technology, $T$. I interpret $T$ broadly, as any factor that increases productivity of educated workers and therefore their relative demand. To make technology differences more explicit, in Figure $2 T$ appears in the isocost: $C\left(w_{0}, w_{1}, p, T\right)$. (Since cities are identical, the amenity is dropped from the indifference curves.) Suppose that, because of technological differences, skilled workers are particularly productive in city B and demand for them is high. Skilled workers move to B, attracted by higher wages. As they do so, they raise average education there. Point 2 represent the equilibrium in city B if there are no spillovers. The wage of educated workers is higher because the technology makes them more productive. The wage of uneducated workers is higher because of complementarity. If the spillover exists, then the isocost curve shifts further to the right. In this case, the true spillover effect is from 2 to 3 , but the observed effect is larger, from 1 to 3 .

In equilibrium, both skill groups are present in both cities. Since workers are free

\footnotetext{
${ }^{8}$ The Figure shows graphically the result of Section 2.1: the effect of an increase in the relative number of college graduates is unambiguously positive for the wage of unskilled workers. If the spillover is strong enough, the effect for skilled workers is positive although lower than the one for unskilled workers.
} 
to migrate from city $\mathrm{A}$ to city $\mathrm{B}$, why are equilibrium wages - net of the compensating differential — not driven to equality? In this model, migration to high wage cities leads to higher rent, making workers indifferent between cities. ${ }^{9}$ Higher nominal wages in a city imply greater productivity. If workers weren't more productive, firms producing goods that are nationally traded would leave high-wage cities and relocate to low wage cities. Although some workers are employed in industries that produce output that it is not nationally traded (local services), firms producing traded goods face the same price everywhere in the nation. Therefore, as long as there are some firms producing traded goods in every city, average productivity has to be higher in cities where nominal wages are higher. The same point is made in Acemoglu and Angrist (2000). ${ }^{10}$

An implication of the model is that the OLS coefficient in a regression of wages of educated workers on share of educated workers can be biased either downward or upward, depending on whether variation in the relative number of educated workers across cities is driven by unobserved supply factors or unobserved demand factors. Consider first the case of Figure 1, where variation in the relative number of educated workers across cities is driven by supply factors. To the extent that amenities are not observed, this unobserved heterogeneity biases the OLS coefficient in a regression of wages of educated workers on share of educated workers downward. In Figure 1 (left panel), the true spillover is the difference between the wage in point 3 and the wage in point 2 . The observed effect is instead the difference between the wage in point 3 and the wage in point 1 , which is smaller than the spillover. ${ }^{11}$ An instrumental variable that is uncorrelated with the amenity generates a consistent estimate of the spillover.

The opposite bias arises from heterogeneity in relative labor demand. Consider Figure 2. The size of the spillover is 2 to 3 . But if $T$ is unobserved, the OLS coefficient in a regression of wages of educated workers on share of educated workers assigns all of the

\footnotetext{
${ }^{9}$ Other models achieve the same result assuming that quality of life is declining in the size of the city (Glaeser et al. 1995). ${ }^{10}$ In the empirical part, I distinguish between workers employed in manufacturing, a traded good industry, and all workers.

${ }^{11}$ In other words, the compensating differential that skilled workers implicitly pay for the amenity is unobserved, and therefore enters the wage of skilled workers as a negative city-specific residual. The correlation between this residual and average education is negative, as skilled workers trade some of their wage for the amenity, so that the OLS coefficient on average education is biased down.
} 
observed correlation between wages and average education to the spillover, and yields an estimate of the spillover that is upward biased (1 to 3). An instrumental variable that is uncorrelated with $\mathrm{T}$ generates a consistent estimate of the spillover. Overall, whether the instrumental variable estimate is larger or smaller than the OLS estimate depends on whether supply heterogeneity dominates demand heterogeneity.

\section{Identification When Individuals and Cities are Heterogeneous}

The basic source of identification in this paper consists in the comparison of wages for otherwise similar individuals who work in cities with different shares of college graduates in the labor force. ${ }^{12}$ The model in the previous section predicts that cities that have a higher share of educated workers will also have higher wages.

This correlation is shown in Figure 3, where the percentage of college graduates is plotted against the regression-adjusted average wage for 282 cities in $1990 .{ }^{13}$ The figure shows that, even after controlling for the private return to education, wages are higher in cities where the labor force is better educated. However, it is not clear whether this documented association is causal. There are many unobserved characteristics of workers and cities that may affect wages and at the same time be correlated with college share.

This section identifies the main sources of omitted variables and develops simple estimation methods that are used to identify the social return to education. In the empirical part of the paper, I first use these methods to gauge the overall effect of higher share of college graduates on the average wage when all skill groups are pooled together. In view of the theoretical discussion in the previous section, I then estimate how higher average education differentially affects the wages of different skill groups. Suppose that the wage

\footnotetext{
${ }^{12}$ Alternative specifications are possible. For example, Krueger and Lindahl (1998) and Topel (1999) use national-level data to estimate the effect of changes in educational attainment on income growth. Metropolitan areas have the advantage of being less arbitrary economic units than countries and having a high degree of economic and social integration.

${ }^{13}$ Data from the 1990 Census are used. The regression-adjusted average wage is obtained by conditioning on individual education, gender, race, Hispanic origin, US citizenship, and a quadratic term in potential experience.
} 
of individual $i$ living in city $c$ in period $t$ is determined by an equation of the form

$$
\log \left(w_{i c t}\right)=X_{i t} \beta_{c t}+\pi P_{c t}+\alpha Z_{c t}+d_{c}+d_{t}+u_{i c t}
$$

where $X_{i t}$ is a vector of individual characteristics, including years of schooling; $P_{c t}$ represents the percentage of college educated workers in the labor force of city c in year t; $Z_{c t}$ is a vector of city characteristics which may be correlated with $P_{c t} ; d_{c}$ represents a city fixed effect; and $d_{t}$ is a year effect. The residual is the sum of three components:

$$
u_{i c t}=\mu_{c} \theta_{i}+\nu_{c t}+\epsilon_{i c t}
$$

where $\theta_{i}$ is a permanent unobservable component of human capital, such as ability or family background; $\mu_{c}$ is a factor loading which represents the return to unobserved skill in city $c ; \nu_{c t}$ represents time-varying shocks to labor demand and supply in city $c$ in period $t$; $\epsilon_{i c t}$ is the transitory component of log wages which is assumed to be independently and identically distributed over individuals, cities and time.

The coefficient of interest is $\pi$, which is the estimate of the effect of college share on average wages after controlling for the private return to education. By letting $\beta_{c t}$ depend on the year and city, the specification of Equation 7 allows for changes over time and across cities in the private return to education. Later, I show that results do not depend on the assumption of linearity of wages in years of schooling.

The model is a city fixed effects specification, and as such, controls for some unobserved heterogeneity at the city level. In particular it sweeps out the effect of permanent city characteristics such as the industrial structure and physical and cultural amenities that confound identification of the effect of college share on wages. However, there may be unobserved correlates of wages and college share that confound identification. Equation 7 identifies two main sources of such omitted variables: individual unobserved heterogeneity $\theta_{i}$ and time-varying shocks to the local labor market, $\nu_{c t}$. I now describe what type of biases these omitted variables introduce and how I deal with them in the empirical work. 


\subsection{Unobserved Ability}

The first major source of omitted variables is individual unobserved heterogeneity. Individuals observed in cities with high human capital may be better workers than individuals with the same observable characteristics who live in cities with low human capital. In terms of equation 7 , this implies that $\operatorname{cov}\left(\theta_{i}, P_{c t}\right)>0$.

For example, a high-school graduate working in a biotechnology firm in San Francisco is probably different along some unobservable dimension from a high-school graduate working in a shoe factory in Miami. Similarly, a lawyer working for a Wall-Street firm in New York is likely to differ from a lawyer in El Paso, TX. This type of sorting may take place if a higher college share in a city is associated with a higher return to unobserved ability, causing higher quality workers to move to cities with higher college share (Borjas, Bronars and Trejo 1992, Rauch 1993). Consider a simple Roy model where different cities reward workers' skills - both observed and unobserved-differently, and mobility decisions are based on comparative advantage. In such a model, workers are not randomly assigned to cities, but choose the city where their skills are most valued and skill-price differentials determine the skill composition of migratory flows. Cities that have an industrial structure that demands more education are also likely to offer a higher price for unobserved ability. In this case, the correlation of high college share with high wages may simply reflect higher unobserved ability of workers rather than higher productivity.

I address the problem of unobserved ability by exploiting the panel structure of the National Longitudinal Survey of Youths (NLSY). By observing the same individual over time, I can control for factors that make an individual permanently more productive. In particular, I absorb the term $\mu_{c} \theta_{i}$ in equation 7 by including a set of individual $\times$ city dummies. By controlling for the individual-city match, one source of variation is lost. Variation that comes from movers is absorbed by the individual $\times$ city dummies. Identification is based on stayers and comes from changes of college share in a city over time. Conditional on a city-individual match, the model estimates what happens to an individual's wage as college 
share around her increases.

The key identifying assumption is that the return to unobserved ability $\mu_{c}$ may vary across cities, but not over time or, if it does change over time, the change is not systematically correlated with college share. Under this assumption, differences in the level of unobserved ability and in return to unobserved ability across cities are absorbed by individual $\times$ city fixed effects. ${ }^{14}$ This specification is more general than the standard individual fixed effects model, where unobserved skills are assumed to be equally valued everywhere. If ability is equally rewarded everywhere, it does not affect mobility choices. The standard individual fixed effects estimator fails to eliminate $\theta_{i}$ for movers. (While in the standard model ability contributes to absolute advantage, in the present model ability contributes to comparative advantage.)

\subsection{Unobserved Heterogeneity in Labor Demand and Supply}

A second source of bias comes from time--varying shocks to local labor market that are correlated with the share of college graduates. Cities differ widely in geographical location, industrial structure, technology, weather and amenities. City fixed effects in equation 7 control for any permanent city-specific characteristics that might bias a simpler crosssectional analysis. But first-differenced models may still be biased by the presence of time-varying factors that are correlated with changes in college share and wages across cities - for example, transitory productivity shocks that attract highly educated workers and raise wages: $\operatorname{cov}\left(\nu_{c t}, S_{c t}\right) \neq 0$. The resulting OLS bias is positive (negative) if positive shocks to wages are associated with increases (decreases) in the share of college graduates in a city. Thus, if variation in college share across cities is driven by unobserved demand factors, OLS is biased upward. For example, the San Jose economy has experienced an unprecedented expansion starting in the second half of the 1980s that was driven by the Silicon Valley computer industry boom. The same boom has attracted a highly educated

\footnotetext{
${ }^{14}$ The conditions under which the general form of a Roy model of self selection is identified are derived in Heckman and Honore' (1990). Heckman and Sedlacek $(1985,1990)$ present general empirical models of self selection with measured and unmeasured heterogeneous skills.
} 
labor force to San Jose. On the other hand, if variation in college share across cities is driven by unobserved supply factors, OLS is biased downward. (See Section 2.2.)

To control for these sources of spurious correlation I turn to the 1970, 1980 and 1990 Censuses. The large sample size of the Censuses allows me to implement two different estimation strategies that try to control for this source of spurious correlation. First, I include in the regressions direct estimates of the transitory shocks to the relative demand of educated workers in the estimating equations. Second, I use two instrumental variables that predict variation in college share but are potentially uncorrelated with unobserved shocks.

\section{(A) The Katz and Murphy Index of Demand Shifts}

To pursue the first of these approaches I adapt a measure of labor demand shifts proposed by Katz and Murphy (1992). The index captures exogenous shifts in the relative demand for different education groups that are predicted by the city industry mix. As noted by Bound and Holzer (1996), different cities specialize in the production of different goods, so that industry-specific demand shocks at the national level have a differential impact on cities. If employment of skilled workers in a given industry increases (decreases) nationally, cities where that industry employs a significant share of the labor force will experience a positive (negative) shock to the labor demand of skilled workers.

The index, a generalization of a widely used measure of between-sector demand shifts, is based on nationwide employment growth in industries, weighted by the city-specific employment share in those industries:

$$
\operatorname{shock}_{j c}=\sum_{s=1}^{46} \eta_{s c} \Delta E_{j s}
$$

where s indexes two-digit industry; $\operatorname{shock}_{j c}$ represent the predicted employment change for workers belonging to education group $\mathrm{j}$ in city $\mathrm{c} ; \eta_{s c}$ is the share of total hours worked in industry $\mathrm{s}$ in city $\mathrm{c}$ in $1980 ; \Delta E_{j s}$ is the change in the log of total hours worked in the same industry nationally between 1980 and 1990 by workers belonging to education group 
j. In the estimations, I include the Katz and Murphy index for two education groups: college or more and less than college. By including in the regressions such measures of labor demand shifts, I hope to account for shocks that affect the relative demand of skilled workers because of a city industrial structure.

\section{(B) Using Lagged Age Structure as an Instrumental Variable}

If the Katz and Murphy measure of demand shifts captures some transitory shocks to the local labor market, but not all, estimates may still be inconsistent. I now turn to instrumental variable estimators. Appropriate instruments must be related to the change in the share of college graduates in a city but orthogonal to unobserved shocks to relative demand and supply of educated labor.

The first instrumental variable is based on differences in the demographic structure of cities. The US labor force is characterized by a long-run trend of increasing education, since the younger cohorts entering the labor force are better educated than the older ones. For example, over the last 25 years, much of the increase in the number of college graduates can be attributed to the entry of the baby boom cohort. To the extent that the relative population shares of different cohorts vary across cities, this will lead to differential trends in college share across cities.

Identification comes from differences in the relative magnitude of the cohorts who enter and leave the labor force between 1980 and 1990. For example, suppose for simplicity that there are 3 age groups: "young", who are about to enter the labor force, "middle", who are and will remain in the labor force, and "old", who are about to retire. Because of the secular trend in increasing education, the share of college graduates is the largest in the young group, and the smallest in the old group. Consider two cities, which are identical in every respect but differ in the age structure. If the share of young and old is larger in city A than in city B, a larger increase in the share of college graduates in the labor force between 1980 and 1990 is expected in city A than in city B. Such increase in the share of college educated workers is driven by the predetermined demographic structure of the city, and it is arguably exogenous to many unobserved shocks to the demand for skilled labor 
between 1980 and 1990.

Formally, the instrument for changes in college share between 1980 and 1990 in city c is defined as a city-specific weighted average of national changes in college share by age-gender group.

$$
I V=\sum_{m} \omega_{m c} \Delta P_{m}
$$

where $\mathrm{m}$ indicates age-gender groups (for example: men 58-60); $\Delta P_{m}$ is the national change in college share for group m between 1980 and 1990; and $\omega_{m c}$ is the share of group m in city c in some base year. Weights $\omega_{m c}$ are estimated using data not only from the labor force, but from the entire population. (The age structure of the labor force may be endogenous.)

One concern is that the age distribution of cities may reflect expected changes in the local economy. Suppose for example that in 1980 people were able to accurately forecast which cities will experience the fastest economic growth between 1980 and 1990 . To the extent that young workers are more mobile than older workers, it is in theory possible that the 1980 age distribution may reflect that expectation.

To lessen any fear that age structure is itself endogenous, I use the 1970 age structure instead of the 1980 one. When 1970 data are used, $\omega_{m c}$ is the proportion of people living in city $\mathrm{c}$ in 1970 who, in 1980, would belong to age group m. ${ }^{15}$ Using the 1970 age structure to predict 1980-1990 changes in education has the advantage of independence from potentially endogenous mobility patterns between 1970 and 1980. (If there was no mobility nor mortality, $\omega_{m c}$ estimated with 1970 data would be on average equal to $\omega_{m c}$ estimated using 1980 data.) It is unlikely that differences across cities in the 1970 age distribution reflect differences in the expected economic performance between 1980 and 1990.

The instrument is exogenous if the 1970 demographic structure is orthogonal to unobservable labor demand shocks between 1980 and 1990. This condition does not require

\footnotetext{
${ }^{15}$ For example, a man who in 1970 is 48 is assigned to the group 'males 58-60'.
} 
that wages at time $t$ be uncorrelated to the age distribution at the same time. Instead, the condition requires that time--varying shocks to the demand of skilled labor experienced by a city between 1980 and 1990 not be associated with the age distribution in $1970 .{ }^{16}$

Some implications of this identification assumption can be tested. In particular, I test whether the 1970 demographic structure of cities is correlated with changes in observable labor market outcomes between 1980 and 1990, such as the net inflow of immigrants (domestic and international), changes in population size, labor force size and labor force participation rate. Finding that the 1970 demographic structure predicts changes in labor market outcomes other than education would cast some doubts on the exogeneity of the instrument. Results presented below indicate that the 1970 age structure is generally orthogonal to changes in labor market outcomes between 1980 and 1990.

(C) Using the Presence of a Land-Grant College as an Instrument

The presence of colleges or universities in a city tends to raise education there. ${ }^{17}$ Using the presence of colleges and universities as an instrumental variable for college share is problematic, however, if their location is non-random. If colleges and universities tend to be located in wealthy areas, for example, then the exogeneity of the instrument is in question. A solution to this problem is to use as the instrument the presence of colleges and universities created in the nineteenth century following the "land-grant movement". ${ }^{18}$

In 1862, the U.S. Congress passed the Morrill Act, the first major federal program to support higher education in the United States. The act gave to every state that had remained in the Union a grant to establish colleges in engineering, agriculture and military science. A second act in 1890 extended the land-grant provisions to the sixteen southern states. Altogether, 73 land-grant colleges and universities were founded, with each state

\footnotetext{
${ }^{16}$ In terms of Equation 7, the instrument is exogenous if

$$
\operatorname{cov}\left[I V,\left(\nu_{c 90}-\nu_{c 80}\right) \mid d_{t}, X, Z\right]=\sum_{m} \Delta P_{m} E\left[\omega_{m c}\left(\nu_{c 90}-\nu_{c 80}\right) \mid d_{t}, X, Z\right]=0
$$

where expectation is taken over c. Equation 11 suggests that a sufficient condition for exogeneity is the absence of correlation between the share of age-gender groups in 1970 and changes in unobserved heterogeneity between 1980 and 1990 , conditional on observables: $E\left[\omega_{m c}\left(\nu_{c 90}-\nu_{c 80}\right) \mid d_{t}, X, Z\right]=0$, for each $\mathrm{m}$.

${ }^{17}$ First, having a local college lowers the cost of going to college. Second, a college graduate is more likely to stay and work in the city where she studied.

${ }^{18}$ I thank David Levine for suggesting this instrument.
} 
having at least one. Although they were originally started as agricultural and technical schools, many have grown into large public universities that have educated almost onefifth of all students seeking degrees in the United States. Even today, the presence of a land-grant college in a city remains a significant determinant of higher education there.

The presence of a land-grant college in a city is good predictor of cross-sectional variation in college share. But it cannot be used as an instrument in the specification that includes city fixed effects, because it would be absorbed by the fixed effect.

Virtually all the metropolitan areas in the sample have colleges or universities, but only some have a land-grant college. The key assumption for the presence of a land grant college to be a valid instrument is that workers in cities with a land grant college are not systematically different from workers with the same education in cities without a land grant college. Since the program that established land-grant colleges was federal and took place more than a century ago, the presence of a land-grant institution is likely to be uncorrelated with unobservable factors that affect wages in 1980 and 1990. Land-grant colleges were often established in rural areas, and their location was not dependent on natural resources or other factors that could make an area wealthier. In fact, judged from today's point of view, the geographical location of land-grant colleges seems close to random. (See Nervis (1962), Williams (1991) and Edmond (1978) for a history of the "land-grant movement"). Cities with land grant colleges are as diverse as Washington DC; Des Moines, IA; Baton Rouge, LA; Knoxville, TN; and Reno, NV. ${ }^{19}$

I show below that workers in cities with a land grant college appear to have similar racial and demographic characteristics to workers in cities without a land grant college. I also show that workers in cities with a land grant college have virtually identical AFQT scores to workers with the same level of education in cities without a land grant college. However,

\footnotetext{
${ }^{19}$ The following MSAs have one or more land-grant colleges: Albany-Schenectady-Troy, NY; Athens, GA; Baton Rouge, LA; Boston, MA; Champaign-Urbana-Rantoul, IL; Columbia, MO; Columbia, SC; Columbus, OH; Des Moines, IA; FargoMoorhead, ND-MN; Fayetteville-Springdale, AR; Fort Collins-Loveland, CO; Gainesville, FL; Greensboro-Winston-SalemHigh Pt., NC; Hartford, CT; Honolulu, HI; Knoxville, TN; Lafayette-West Lafayette, IN; Lansing-East Lansing, MI; Lexington-Fayette, KY; Lincoln, NE; Macon-Warner Robins, GA; Madison, WI; Minneapolis-St. Paul, MN-WI; Nashville, TN; Pine Bluff, AR; Portsmouth-Dover-Rochester, NH-ME; Providence, RI; Raleigh-Durham, NC; Reno, NV; RichmondPetersburg, VA; Riverside-San Bernardino, CA; Sacramento, CA; San Francisco, CA; State College, PA; Tallahassee, FL; Tucson, AZ; Washington, DC-MD-VA and Wilmington, DE-MD. For the complete list of land-grant colleges see Appendix in Nervis (1962).
} 
the finding of no difference in mean AFQT in the two types of cities does not necessarily imply that the presence of a land-grant college does not reflect differences in the ability of the work force. The mean AFQT conditional on schooling achievement should be lower in cities with a land grant college, as marginal college completers have lower mean AFQTs than the average college completer. ${ }^{20}$

\section{Estimates of Social Returns Using NLSY Data}

In this Section, I present estimates of the external return to education based on longitudinal data from the NLSY. The focus is on controlling for unobserved ability. In light of the discussion in Section 3.1, the concern is that individuals observed in cities with high human capital are inherently better workers than individuals with the same observable characteristics who live in cities with low human capital, as predicted by a Roy model of self-selection. By including individual $\times$ city fixed effects, I can control for differences in the level of unobserved ability and in return to unobserved ability across cities. The results obtained lend support to the hypothesis that unobserved individual ability does not play a major role in explaining the relationship between wages and college share.

I use the Metropolitan Statistical Area (MSA) as a local labor market. MSA's are defined to include local economic regions with populations of at least 100,000: most MSA's contain more than one county. The data come from a confidential version of the NLSY that identifies the metropolitan area of residence. The sample has longitudinal earnings and city of residence information from 1979 to 1994. I drop youths under 23 because they may still be in school, so only individuals who are 23 to 37 years old are in the sample. Using the confidential MSA codes, I match individual-level data with data on college share in the metropolitan areas of residence from the Census. I interpolate college share in the years

\footnotetext{
${ }^{20}$ Another potential concern is that in college towns such as Urbana IL or Gainesville FL, the university may be a major employer. If teachers and staff wages are above average, this could bias the results. To account for this possibility, I re-estimated the models excluding workers employed in colleges and universities, libraries and educational services. I also re-estimated the models including a college town dummy variable. The results did not change in either case. This is not surprising, because cities in the sample are typically large metropolitan areas with many industries, and the university is rarely the only large employer.
} 
for which Census figures are not available. ${ }^{21}$ Summary statistics are in Table 1. The Data Appendix provides more detailed information on the NLSY sample and the matching.

The top panel in Table 2 reports estimates of equation 7 when the private return to education $\beta_{t}$ is allowed to vary over time. Later, a more general specification is estimated, where the private return to education varies both over time and across cities. Regressors include the share of college educated workers in a city, a vector of individual characteristics - including years of schooling, sex, race, Hispanic origin, a quadratic term in potential experience - and a set of year dummies. Standard errors in all specifications are adjusted for the grouped nature of the data. The first column reports estimates obtained while ignoring the panel structure of the data. Observations for the same individual for different years are treated as if they referred to different individuals. The estimate of the external return to education suggests that a 1 percentage point increase in the share of college educated workers in a city is associated with a $1.31 \%$ increase in wages. The coefficients on the other covariates are consistent with findings in the human capital earnings function literature. For example, the estimated private return to education rises from 0.07 in 1980 to 0.10 in 1994.

To control for heterogeneity across metropolitan areas that may cause bias in the cross section, city fixed effects are included in column 2. The estimated external return conditional on city fixed effects is $1.13 \%$.

Column 3 reports results obtained including both city and individual fixed effects. Any individual permanent characteristics, such as ability or family background, are controlled for by a set of individual dummies. In this specification, identification comes from two sources. First, individuals may change cities. Second, college share changes in a city over time. The estimated coefficient is almost unchanged. ${ }^{22}$

One problem with the model that includes individual fixed effects is that individuals

\footnotetext{
${ }^{21}$ An alternative would have been to use estimates obtained yearly from the Current Population Survey. Sample size considerations suggested that interpolated figures from the Census are better. See the Data Appendix.

${ }^{22}$ The precision of the estimator does not decrease when the individual dummies are included. The reason is that variation in the variable of interest, college share, is at the city-time level, not at the individual level. Although there are 44,891 observations in the regression, the effective sample size for identification of the coefficient on college share is only 201 times 16 (number of cities times number of years).
} 
do not change city randomly, but they self-select into cities based on their comparative advantage. If the return to individual ability varies across cities, a model that includes individual fixed effects may be misspecified (Section 3.1). In terms of Equation 7, individual fixed effects impose the restriction that the return to ability, $\mu_{c}$, is equal everywhere. In a more general model where the return to ability differs across cities, an individual fixed effects specification fails to absorb the error component $\mu_{c} \theta_{i}$. To control for unobserved heterogeneity at the individual-city level, individual $\times$ city fixed effects are included. In this specification, everything that is specific to an individual-city pair is absorbed by the fixed effect.

By keeping constant the individual-city match, variation that comes from individuals who change cities is lost. Identification is based on stayers and comes from changes of college share in a city over time. The model estimates what happens to the wage of a given individual in a given city as college share around her increases over time. The estimated external return to education is 1.08, slightly lower than the individual fixed effects estimate, but still significantly different from zero (column 4). From column 4 I conclude that unobserved ability is not a major source of bias. It it useful to remember that this conclusion is based on the assumption that the return to unobserved ability in a city, $\mu_{c}$, is fixed over time. In a more general model, where the return to ability varies by city and time $\left(\mu_{c t}\right)$, estimates conditional on city $\times$ individual fixed effect would not necessarily be consistent.

The next two models attempt to account for time-varying factors that affect wages and may be correlated with college share. The model in column 5 includes the local unemployment rate. I use local unemployment rate as a proxy for labor demand shifts potentially correlated with college share. ${ }^{23}$ The model in column 6 includes the unemployment rate, the Katz and Murphy index, and a vector of other city characteristics potentially correlated with college share: proportion of Blacks, Hispanics, females and US citizens in a city labor force. Estimates of the social return to education do not seem to be sensitive to

\footnotetext{
${ }^{23}$ Unemployment rate is from the Bureau of Labor Statistics and is at the state level.
} 
the inclusion of such controls. The coefficient on unemployment rate (not reported in the table) is negative, as expected: $-0.004(0.0025)$. Most of the coefficients on the other city controls are not significant. ${ }^{24}$

The estimate in column 6 implies that during the 1980s a one percentage point increase in a city's college share was responsible for an increase in wages of just above $1 \%$. Translating the estimated coefficient on college share into the effect of a one year increase in average schooling (under the assumption that the share of college graduate increases by 25 percentage points and the share of high-school graduates decreases by the same amount) yields a coefficient of .25, significantly larger than the private return to schooling. However, in interpreting the size of the estimated effect, one should keep in mind that this is not an estimate of the spillover. Equation 6 makes clear that the estimated effect is the sum of the spillover plus two other terms, whose sum is positive. Moreover, increases in college share observed in the data never get close to 25 percentage points. Actual increases in college share are typically ten times smaller over the ten year period under consideration. The reported coefficients estimate the effect of changes in the fraction of college graduates at the current margin. The effects at values outside the data may not be well approximated by the estimates in this paper. Specifically, the median yearly increase in the percentage of college graduates is 0.2 percentage points. Such an increase would imply an increase in wages of $0.24 \%$. For a worker who earns $\$ 25,000$, that effect amounts to about $\$ 62$ per year.

It is possible that cities where college share is higher also have a higher cost of living. For the purpose of this paper, however, nominal wages (i.e. wages unadjusted for cost of living) are the correct dependent variable. Higher nominal wages in a city imply greater productivity. See section 2.2 and Acemoglu and Angrist (2000). In any case, conditioning on cost of living differences makes little difference. Column 7 reports estimates obtained by augmenting the estimated model with the cost of housing. ${ }^{25}$ The coefficients on average

\footnotetext{
${ }^{24}$ The coefficients on percentage female, Hispanic, black, US citizens in the labor force are, respectively: $0.59(0.68) ;-1.18$ $(0.70) ; 0.37(0.41) ;-2.19(0.88)$.

${ }^{25}$ As a measure of cost of housing I use the 'fair market rent' calculated for each MSA by the Department of Housing and Urban Development. The 'fair market rent' is used as a cost of living adjustment in some federal welfare programs. It
} 
education are virtually unchanged from column 6 .

In column 8 , I re-estimate the model of column 6 including only workers in manufacturing, the most important industry producing traded goods. The coefficient for manufacturing workers is 1.26 , similar to the corresponding coefficient for all workers.

The bottom panel of Table 2 reports estimates obtained by allowing the private return to education to vary over time and across cities. With 202 cities and 16 years, an unrestricted specification would consume too many degrees of freedom. Instead I estimate a specification in which the private return to education $\beta_{c t}$ is the sum of two components, a city effect and a time effect: $\beta_{c t}=\beta_{c}+\beta_{t}$. These components allow observed rates of return to vary because of differences in the return to schooling across cities $\left(\beta_{c}\right)$ and time $\left(\beta_{t}\right) .{ }^{26}$ Estimates of the external return in panel B are qualitatively similar to the corresponding estimates in panel A.

I conclude this section by reporting estimates from alternative specifications designed to probe the robustness of the results in Table 2. At the top of Table 3 is the base case, from column 6 and 7 of Table 2 (upper panel). I start by estimating separate effects for men and women. The estimates in row 2 and 3 are the coefficients on the interaction of college share and a dummy for men, and college share and a dummy for women, respectively. I can not reject the hypothesis that the coefficients for men and women are identical (the p-value is 0.82$)$.

I now turn to models where the private return to education is not linear in years of schooling. Misspecification of the form of the private return to education could induce bias in the estimate of the external return. Estimates in row 4 are obtained by including a dummy for college graduation, while estimates in row 5 include dummies for each year of schooling. This last specification is the more flexible specification suggested by Heckman, Layne-Farrar and Todd (1996). The change in the estimated external return to education

\footnotetext{
corresponds to the $45^{\text {th }}$ percentile of rents for a 2-bedroom apartment in each MSA. The $R^{2}$ in a regression of 1990 housing cost on 1980 housing cost is 0.62 .

${ }^{26}$ This specification is consistent with a uniform change in the return to education across cities. If changes in the private return to education during the 1980 s were different across cities, failure to let the coefficient on individual education vary by city and year could bias the coefficient on college share.
} 
is minimal.

Although the models estimated so far allow for the private return to schooling to vary over time, the return to unobserved ability is not allowed to vary over time. One concern is that this omission may be biasing the coefficient on college share upward. One way to partially account for ability is to use AFQT scores, and allow the return to AFQT scores to vary over time. Estimates in row 6 are from models that include AFQT $\times$ year dummies. Estimates in row 7 are from models that allow the return to AFQT scores to vary over time and across cities (in the same way that the return to schooling is allowed to vary over time and across cities in Table 2). Since AFQT is missing for some individuals, row 8 reports estimates of the basic model for the sample of individuals with non-missing AFQT scores. The comparison between estimates in row 6 and with estimates in row 8 suggests that unobserved ability in unlikely to bias the results upward.

\section{Separate Estimates By Education Group Using Census Data}

Estimates of the external return to education in Section 4 are obtained by pooling all education groups together and therefore represent an average effect across education groups. But the fact that average wage is found to increase when college share increases is not in and of itself an indicator of spillovers. The theoretical model in Section 2 indicates that the external return to education is the sum of two effects: the standard imperfect substitution effect associated with a shift in college share and the spillover, if there is any. A conventional model without spillovers but with imperfect substitution between low and high education workers can explain a positive correlation between college share and average wages.

In this section, I separately estimate the effect of college share on the wages of different education groups. A key prediction of the model presented in Section 2 is that, irrespective of the magnitude of the spillover, the external return associated with an increase in college share should be unambiguously positive for unskilled workers. If the spillover is strong 
enough, the coefficient for skilled workers should also be positive, but lower than the one for unskilled workers. If the supply effect is stronger than the spillover, though, the coefficient for skilled workers should be negative. By looking only at the effect on wages of uneducated workers, one cannot separate imperfect substitution from the spillover. Only by looking at the effect of an increase in the supply of college graduates on their own wage can one directly test for the presence of spillovers.

I divide the sample into four education groups: less than high-school, high-school, some college and college or more. I then estimate a model similar to the one in Section 4 separately for each group. In this specification, the units of observation are city-educationyear group cells. Since these education-city-year cells are small in the NLSY, I turn to the Census. In particular I use the Public Use Micro Samples (PUMS) of the 1980 and 1990 Censuses of Population, which include 1.69 million observations on working adults in 1980 and 1.98 million working adults in 1990. Although the longitudinal dimension is lost, the large sample size of the Censuses guarantees that all of the education-city-year cells are reasonably large. A total of 282 MSAs can be identified and matched across the 1980 and 1990 Censuses. Summary statistics are in Table 1. The Data Appendix provides more detailed information on the procedures used to identify the MSAs in each year and match MSAs across them.

Results in the previous section indicate that unobserved individual heterogeneity is unlikely to be a major source of bias. In this section I account for a second potential source of bias: city-specific time--varying shocks that affect both college share and wages (Section 3.2). To do so, I first include in the estimating equations a direct estimate of such shocks, based on the Katz and Murphy index. The index captures shocks that affect a city because of its industrial composition. I then try to increase the robustness of the estimates to all types of shocks by using two instrumental variables that predict variation in college share but are potentially uncorrelated with unobservable shocks. 


\subsection{OLS Estimates}

In order to check that NLSY and Census data generate comparable results, I start by reproducing the specification adopted in Section 4, where all education groups are pooled together. Because of the large sample size, a two-stage estimation procedure is adopted for all models that use Census data. ${ }^{27}$

The top panel of Table 4 presents first-differenced OLS estimates of the relationship between the share of college graduates and the level of wages in a city for the full sample. According to city fixed-effects estimates in column 1, a one percentage point increase in the share of college graduates in a city is associated with an increase in wages of $1.48 \%$. The corresponding estimate obtained using NLSY data is 1.13 (Table 2). The fact that the estimate obtained using Census data is larger than the corresponding estimate obtained using NLSY data may reflect the measurement error in college share used for the NLSY estimates. The coefficients on the remaining variables - not reported in the table-are similar to the ones in Table $2 .^{28}$

Including the unemployment rate and other city characteristics (column 2) slightly lowers the estimated coefficient to 1.32. Including the Katz and Murphy index (column 3) lowers the estimated external return a bit more. The fact that the Katz and Murphy index and the unemployment rate do not significantly change the estimates of external return lends some support to the view that the bias introduced by demand shocks is not large. Including cost of housing has a small effect on the estimated social return (column 4). When the sample is restricted to manufacturing workers, estimates increase slightly (see

\footnotetext{
${ }^{27}$ In the first stage, the regression-adjusted mean wage in city c at time $t, \hat{\alpha}_{c t}$, is obtained from the following regression: $\log \left(w_{i c t}\right)=\alpha_{c t}+X_{i t} \beta_{t}+v_{i c t}$ where $X_{i c t}$ is a vector of individual characteristics including education, sex, race, Hispanic origin, U.S. citizenship and a quadratic term in potential experience; and $\alpha_{c t}$ is a set of city-time dummies that can be interpreted as a vector of adjusted city average wages. This equation is estimated separately for 1980 and 1990 . In the second stage, $\hat{\alpha}_{c t}$ is regressed on college share in the city, controlling for city fixed-effects and time-varying city characteristics: $\hat{\alpha}_{c t}=d_{c}+d_{t}+\pi P_{c t}+\alpha Z_{c t}+\epsilon_{c t}$. All the regressions are weighted by the number of observations per city to account for differences in the precision of the first stage estimates. This weighted two-step procedure gives rise to estimates that are consistent although asymptotically less efficient that optimally weighted two-step estimates, which are numerically equal to one-step estimates. The two-step procedure yields standard errors that account for the grouped structure of the data.

${ }^{28}$ The private return to education is $0.085(0.0001)$ in 1990 and $0.062(0.0001)$ in 1980 . The 1990 coefficients on the quadratic term in experience are $0.040(0.0001)$ and $-0.0006(0.0000)$ for the linear and squared term, respectively. The corresponding coefficients for 1980 are $0.033(0.0001)$ and $-0.0004(0.0000)$. The 1990 coefficients on black, Hispanic, female and US citizens are $-0.119(0.001),-0.076(0.001),-0.313(0.0008)$ and $0.132(0.001)$, respectively. The corresponding coefficients for 1980 are -0.078 (0.001), $-0.049(0.002),-0.402(0.0009), 0.093(0.002)$.
} 
bottom panel of Table 4). ${ }^{29}$

Having established that city fixed effects Census estimates are comparable to NLSY estimates, I separately estimate the effect of college share on the wages of different education groups. Table 5 presents estimates of the effect of changes in college share on changes in each group's regression-adjusted mean wage. First-differenced OLS estimates in column 1 confirm that the coefficient is larger for less educated groups, as predicted by a conventional demand and supply model. But even for college graduates, the effect of an increase in college share is positive, as predicted by a model that includes both conventional demand and supply factors and spillovers. Including the Katz and Murphy index (column 2) lowers the estimates, but does not change the pattern across education groups.

\subsection{Instrumental Variable Estimates: Age Structure}

I now turn to instrumental variable estimates based on the lagged age structure. As discussed in Section 3.2, the instrument is exogenous if the 1970 demographic structure is orthogonal to unobservable labor demand shocks between 1980 and 1990. Some implications of this identification assumption can be tested. In particular, I test whether 1970 demographic structure is correlated with 1980-1990 geographical mobility, changes in labor force participation, and other labor market outcomes. The observation of a correlation between age structure and labor market outcomes other than wages may cast some doubt on the exogeneity of the instruments. The potential for correlation between demographic structure and mobility is a concern. This would happen if, for example, cities with a disproportionate share of foreign immigrants were also younger. A tendency of newly-arrived immigrants to move to enclaves established by earlier immigrants (Bartel 1989), implies that the instrument would predict immigrant inflows. A second concern is the potential for correlation of demographic structure with labor force participation.

Table 6 reports the partial correlation between the share of 3 age groups in 1970 and the net inflow of immigrants (domestic and international) and the changes in population

\footnotetext{
${ }^{29}$ The reverse is true for the NLSY, where estimates for manufacturing workers are slightly lower than those for all workers.
} 
size, labor force size and labor force participation rate between 1980 and 1990. Entries in the first column are,+ 0 or - indicating whether the regression of percentage change in population on the share in each demographic group yields a positive, insignificant or negative coefficient. Control variables that appear in the wage equations are included. Entries in the remaining 4 columns are obtained similarly. As expected, the demographic structure in 1970 is in general uncorrelated with changes between 1980 and 1990 . The only exception is the inflow of foreign immigrants.

Column 3 in Table 5 (top panel) shows results from the first stage regression of changes in college share on the instrument. The age structure of a city in 1970 is a good predictor of changes in college share between 1980 and 1990. Instrumental variables estimates of the effect of changes in college share on changes in each group regression-adjusted mean wage are in the bottom panel. ${ }^{30}$ First-differenced IV estimates in column 3 confirm that the coefficient is larger for less educated groups, and smaller, but still positive for college graduates. Including the Katz and Murphy index (column 4) yields slightly lower estimates. According to first-differenced estimates in column 4, a $1 \%$ increase in the share of college educated workers raises high-school drop-outs' wages by $1.9 \%$, high-school graduates' wages by $1.6 \%$, wages of workers with some college by $1.2 \%$ and those of college graduates by 0.4\%. To aid in the interpretation of the magnitude of the coefficients, consider an average worker earning $\$ 25,000$ a year in a city like Bakersfield, CA, or Lancaster, PA, which experienced increases in the share of college graduates close to the median. The predicted yearly increase in earnings caused by increases in college share is $\$ 95$ a year for an highschool drop-out, $\$ 80$ for an high-school graduate and $\$ 20$ for a college graduate.

This evidence is consistent with the prediction of a model which includes both conventional demand and supply factors and spillovers. Both imperfect substitution and the spillover increase the wage of uneducated workers. The impact on the wage of educated workers, however, is determined by two competing forces: the conventional supply effect,

\footnotetext{
${ }^{30}$ For space consideration, I do not report here IV estimates obtained by pooling all education groups together. These estimates are similar to their OLS counterparts in Table 4. Depending on the specification, they are between $1.17(0.41)$ and $1.29(0.40)$. Table 8 below reports one of the IV estimates obtained by pooling all education groups together.
} 
which makes the wage move along a downward sloping demand curve, and the spillover, which raises productivity. Even for college graduates, the spillover effect seems to be large enough to generate a positive wage gain in better-educated cities. This finding implies that the existence of human capital spillovers cannot be rejected. Standard demand and supply theory would predict that in the absence of spillovers, an increase in the supply of college educated workers would lower their wage.

A limitation of the framework adopted here is the implicit assumption that workers in the same education group are perfect substitutes. If educated workers are imperfect substitutes, then the effect of the changes in percentage of college graduates on wages of college graduates would not necessarily represent a spillover, but could in part be explained by imperfect substitution.

\subsection{Instrumental Variable Estimates: Land-Grant Colleges}

I now turn to the second instrumental variable. The presence of a land-grant college can be used as an instrumental variable only in cross-sectional specifications, as it does not vary over time.

All cities in the sample have colleges or universities, but only 39 have a land grant college. Figure 4 plots the difference in the distribution of schooling for cities with and without a land-grant college. The probability of attending college is higher in cities with a land-grant college, while the probability of high-school graduation is lower. The figure suggests that some students would stop studying after high-school if they didn't live near a land-grant college, but go to college if they do. The difference in probability declines at lower grades. Figure 4 is consistent with the assumption that the presence of a land-grant college increases the probability of college graduation, and not vice versa. If the presence of a land-grant college captured unobservable characteristics of the area, such as tastes for education, then we would expect that in cities with a land grant college not only the

probability of going to college, but also the probabilities of graduating from high-school and attending some college, would be higher. 
Table 7 quantifies the difference for 4 education groups. The table reports estimates of a regression of the percentage of workers in each group on a dummy equal one if the city has a land-grant college and other wage equation covariates. The presence of a land-grant college raises the percentage of college graduates in the city in 1990 by 0.05 . (1980 results are similar). This is a remarkable effect, given that average college share is 0.25 .

As far as other characteristics (such as percentage blacks, females, citized and unemployed), cities with a land grant college appear generally similar to cities without a land grant college. ${ }^{31}$ Also, conditional on years of schooling and other individual characteristics, AFQT scores of workers in cities with a land-grant college are similar to the AFQT scores of workers in cities without a land-grant college. ${ }^{32}$

Columns 5 to 8 in Table 5 report cross-sectional estimates of the social return to education for 1980 and 1990 using land grant college as an instrument for college share in columns 6 and 8. All cross-sectional models include region effects. The inverse relationship predicted by the model between level of education and size of the coefficient is not as clean as in the first-differenced models. While cross-sectional IV estimates for college graduates (between 0.45 and 0.55 ) are very similar to the corresponding first-differenced estimates (0.47), cross-sectional IV estimates for less educated groups are lower than the corresponding first-differenced estimates.

\section{Robustness Checks}

In this Section, I report estimates from several alternative specifications designed to probe the robustness of the main results of the paper. For space considerations, I present only estimates that pool all education groups together. At the top of Table 8 is the base case, the first-differenced OLS estimate from column 3 of Table 4 and the corresponding first-

\footnotetext{
${ }^{31}$ The percentage of blacks in cities with and without land grant college is respectively 0.108 and 0.113 ; percentage of females is 0.460 and 0.444 ; the percentage of US citizens is 0.962 and 0.956 ; the unemployment rate is 5.79 and 6.02 and average years of experience are 18.43 and 19.27 . The only sizable difference is found in the percentage Hispanic, which is 0.041 and 0.070 , respectively.

${ }^{32} \mathrm{~A}$ regression of AFQT scores on the land-grant dummy, years of schooling, sex and race yields a coefficient on the land-grant dummy equal to $-0.40(0.82)\left(R^{2}\right.$ is 0.50$)$.
} 
differenced IV estimate (obtained using the 1970 age structure as an instrument).

I start by estimating separate coefficients for men and women (row 2 and 3). The OLS coefficient for men is similar to the one for women. The IV coefficient for men is smaller than the one for women, but not statistically different.

I now turn to models where the private return to education is not linear in years of schooling. Estimates in row 4 are obtained by including only a dummy for college graduation, while estimates in row 5 include dummies for each year of schooling. The change in the estimated external return to education is not large.

Most of the variation that identifies the instrumental variables comes from differences across cities in the share of young and old age groups in 1970. In particular, if there was no geographical mobility, people entered the labor force only when they are young and exited only when old, identification of the instrument would come only from the tails of the age distribution. In row 6 and 7, I try two alternative definition of the instrument. First, I use an instrument based only on variation across cities in the share of young individuals (less than 35) and old individuals (more than 55). Second, I use an instrument based only on variation across cities in the share of young individuals. When I use the instrument based only on the share of young and old individuals, the IV estimate is 1.61 (row 6). When I use the instrument based only on the share of young individuals, the estimate rises to 1.93. The standard errors increases substantially. This loss in precision is to be expected, because only part of the variation in age distribution across cities is used by the estimator in rows 6 and 7 .

Thus far, I have assigned individuals to a city on the basis of their residence. MSAs are large enough that for most people the city of residence coincides with that of work. To test whether results are sensitive to commuters who live and work in different cities, I repeat the analysis assigning individuals on the basis of the MSA where they work (row 8). As expected, results are not sensitive to the small number of workers who commute outside their MSA of residence.

In row 9, I allow for the presence of inter-industry wage differentials. Including 29 
industry dummies takes any industry composition effect out of the adjusted mean wage.

Estimates in row 9 suggest that industry composition does not drive the results. The occupation composition could also induce spurious correlation between wages and education. When four occupation dummies are included (row 10), results do not change appreciably.

College towns, where the population is younger and more educated, may pose a problem for the age structure instrument, since demand for skills rose in the 1980s. To address this issue, a college town dummy variable is included, and results do not change (row 11).

I consider the possibility that results are driven by city size. The concern is that larger cities attract a better educated labor force and pay higher wages. This is unlikely to be a major problem, as city fixed effects absorb permanent differences in city size. Estimates in row 12 - obtained by conditioning on changes in city size - confirm that results are not driven by heterogeneity in city size.

To check the sensitivity of the estimate to the presence of outliers, I estimate a median regression. The LAD estimate in row 13 suggests that outliers are not driving the results.

Finally, one may be concerned that changes in tax rates may be correlated with the fraction of college graduates. I collected data on state individual income tax rates for 1980 and 1990 from the periodical "Facts and Figures on Government Finance", published by the Tax Foundation. Given that my dependent variable is wages, the use of state individual income tax rates seem appropriate. I found no statistically significant relationship between changes in tax rates and the fraction of college graduates. ${ }^{33}$

\section{Extensions and Related Literature}

The results presented so far have focused on the effect of college share on wages. The specification adopted is restrictive in two ways. First, it pools together workers with

\footnotetext{
${ }^{33} \mathrm{~A}$ regression of the change in the tax rate for the highest bracket on the change in college share yields a coefficient of $0.34(0.36)$. A regression of the change in the tax rate for the lowest bracket on the change in college share also yields an insignificant coefficient. Notice however that the top and bottom tax rates are an imperfect proxy for the level of fiscal pressure in a state, since the state tax systems differ in many other dimensions. For example, the income levels that defines the highest and lowest brackets, personal exemptions and deductibility of federal tax income differ across states. Most of these difference across states are permanent, and are therefore absorbed by the city fixed effects.
} 
college degrees and graduate degrees. Second, it ignores spillovers that occur at lower levels of the education distribution. For example, increases in high-school graduation rates may benefit high-school drop-outs. In Table 9 I present separate OLS estimates of the spillovers generated by increases in the share of workers with graduate degrees, college degrees and high-school degrees. Unlike the rest of the paper, the category 'college' here refers to individuals with exactly 16 years of schooling. The category 'graduate school' refers to individuals with 17 or more years of schooling. The estimates in the table indicate that there are large spillovers from increases in the share of workers with graduate degrees and college degrees. The coefficients on the share of high-school graduates are much smaller, and generally not different from zero.

Few other studies have attempted to estimate social return to education. Rauch (1993) is the first to exploit differences in human capital across cities to identify spillovers, but treats average schooling as historically predetermined. Acemoglu and Angrist (2000) use state variation in child labor laws and compulsory attendance laws to instrument for average schooling. While their OLS estimates of the external return to education are qualitatively consistent with OLS estimates presented here, their IV estimates are smaller and in most cases not significantly different from zero. This is consistent with Krueger and Lindahl (1998), who argue that if human capital is expanded at higher levels of education, the benefits of the spillover are in the form of technological progress and higher productivity. If human capital is expanded at lower levels, the benefits are in the form of reductions in crime and lower welfare participation.

There are three differences between this study and Acemoglu and Angrist (2000). First, child labor and compulsory attendance laws affect educational attainment in the lower part of the distribution, mostly in middle school or high school. On the contrary, I identify spillovers using variation in the number of college graduates, i.e. the upper part of the distribution. There is no theoretical reason to expect that a one year increase in a city average education obtained by a rise in the number of those who finish high-school has the same effect as a similar increase in average education obtained by a rise in the number 
of those who graduate from college. Results in table 9 suggest that the former effect is indeed smaller than the latter.

A second difference is that the definition of labor market in Acemoglu and Angrist (2000) is the state, while here it is the city. I have re-estimated my models using states as units of analysis. The estimated coefficients show patterns similar to the patterns shown by coefficients obtained when cities are units of analysis, but they are generally about $20 \%-30 \%$ smaller. $^{34}$

A final difference concerns the period under consideration. Most models in Acemoglu and Angrist (2000) are estimated using 1960-1980 Census data. When they add data from the 1990 Census, they find statistically positive external returns when child labor laws are used as instruments. Since the private return to education increased during the 1980's, this finding may reflect a change in the social value of human capital. They suggest, instead, that this finding is more likely due to increased measurement error in the schooling variable in $1990 .^{35}$ If there is measurement error in imputed years of schooling, the private return to education is underestimated and the social return is overestimated.

I investigate the effect of measurement error by forcing the private return to education to be $10 \%$ or $20 \%$ larger than it would be in an unconstrained regression. If the external return to education is picking up some of the bias from the private return, then we should see that the coefficient on college share is significantly different in the constrained and unconstrained regression. When the private return to education in 1980 and 1990 is inflated by $10 \%$, the estimated coefficient on college share decreases as expected, but the difference is not significant. ${ }^{36}$ This remains true when private return to education is inflated by $20 \% .^{37}$ Finally, I turn to the case where years of schooling is measured with error only in 1990, as

\footnotetext{
${ }^{34}$ For example, the OLS coefficient on state college share in a regression similar to the one in Table 4, column 1 is 1.03 (0.58) instead of $1.48(0.16)$.

${ }^{35}$ In the 1980 Census, the survey asked respondents their highest grade attended, and whether they had completed that grade. Beginning with the 1990 Census, the survey has asked instead about individuals' highest degree received. In order to use a continuous years of schooling variable in regressions based on 1990 data, I impute years of schooling based on tabulations from the 1992 CPS that contains responses to both educational attainment questions. Years of education are assigned to education codes used in 1990 Census following Table 1 in Kominsky and Siegel (1994). The imputation procedure that I adopt is widely used, and has been shown to reproduce accurately estimates of the private return to education that would be obtained by using a continuous years of schooling variable (Jaeger 1997).

${ }^{36}$ The first-differenced OLS estimate changes from $1.27(0.11)$ (Table 4 column 3$)$ to $1.22(0.11)$. The corresponding first-differenced IV estimate changes from $1.29(0.38)$ to $1.23(0.40)$.

${ }^{37}$ First-differenced OLS and IV estimates become $1.18(0.11)$ and $1.21(0.40)$, respectively.
} 
Acemoglu and Angrist (2000) suggest. Inflating only the 1990 private return to education has little effect on the estimated external return. ${ }^{38}$ I conclude that attenuation bias in the estimate of private return to education would have only a minor effect on estimates of the coefficient on college share.

Heckman et al. (1996) provide evidence of the effect of the stock of education in a region on the return to schooling. They do not control for endogeneity but they focus on issues of regional self-selection and functional form.

\section{Conclusion}

The goal of this paper is to find a credible methodology for identifying and measuring the social return to higher education. The argument is divided into two parts. In the first part, the social return to education is estimated by pooling together all education groups. I consider the possibility that cities with a more educated labor force also have higher levels of unobserved ability. I use a special version of the National Longitudinal Survey of Youth to control for differences in unobserved ability across individuals and differences in the return to skills across cities. I turn to the Census and investigate the possibility that there are city-wide labor demand shocks that increase wages in a city and attract skilled workers. I account for this possibility both directly, by estimating these shocks with an index of demand shifts and indirectly, by instrumental variables techniques. The external return estimated using Census data is remarkably similar to the external return estimated using NLSY data. The most robust estimates are between $0.6 \%$ and $1.2 \%$.

The second part of the paper presents separate estimates of the effect of an increase in the percent college graduates on the wages of four education groups. Economic theory predicts that the effect of an increase in college share on the wage of low education workers is positive, since it is the sum of two positive components: imperfect substitution and spillover effect, if there is any. On the contrary, the effect of an increase of college share

\footnotetext{
${ }^{38}$ First-differenced OLS and IV estimates become $1.19(0.11)$ and $1.21(0.40)$, respectively.
} 
on the wage of high education workers is the sum of two opposite forces: the decrease in the private return to education and the spillover effect.

I find that the coefficient on the percent college graduates is larger for less educated groups, as predicted by a conventional demand and supply model. But even for college graduates, an increase in the percent college graduates increases wages, suggesting that the spillover effect is larger than the move down the demand curve. First-differenced IV estimates suggest that a one percent increase in the proportion of college educated workers raises the wage of high school dropouts, high school graduates, workers with some college, and college graduates by $1.9 \%, 1.6 \%, 1.2 \%$ and $0.4 \%$, respectively.

Compare a city like El Paso, TX, a poor border community, with San Jose, CA, which lies in the heart of Silicon Valley. The former, with the eighth lowest average education level in the US, experienced virtually no increase in the proportion of college graduates in the 1980's. The latter, with one of the highest levels of average education, witnessed a $5.1 \%$ increase in the proportion of college graduates. Findings in this paper suggest that in San Jose the external return to education may have accounted for wage increases among high-school graduates and college graduates of $8 \%$ and $2 \%$, respectively. These increases occurred over the ten year period between 1980 and 1990. (Note however that the increase in the percent of college graduates experienced by San Jose is not typical at all, being more than twice as large as the median increase.) No wage increase was caused by the external return to education in El Paso.

In interpreting the magnitude of the estimated coefficients, one should remember that these coefficients represent partial equilibrium effects, obtained by increasing the share of college graduates in a city holding constant the share of college graduates in all other cities. The estimated effect does not generalize to a national increase in college share. 


\section{References}

Acemoglu, D. (1996), 'A microfundation for social increasing returns in human capital accumulation', Quarterly Journal of Economics pp. 779-804.

Acemoglu, D. (1998), 'Why do new technologies complement skills? directed technical change and wage inequality', Quarterly Journal of Economics 113, 1055-1090.

Acemoglu, D. and Angrist, J. (2000), 'How large are human capital externalities? evidence from compulsory schooling laws', NBER Macro Annual .

Altonji, J. and Card, D. (1991), The effects of immigration on the labor market outcomes of less skilled natives, in J. Abowd and R. Freeman, eds, 'Immigration, Trade and Labor', University of Chicago Press.

Arrow, K. (1962), Economic welfare and the allocation of resources for invention, in R. Nelson, ed., 'The Rate and Direction of Inventive Activity', Princeton University Press.

Bartel, A. P. (1989), 'Where do the new u.s. immigrants live?', Journal of Labor Economics 7, 371-391.

Beeson, P. and Eberts, R. (1989), 'Identifying productivity and amenity effects in interurban wage differentials', Review of Economics and Statistics 71, 443-452.

Blomquist, G. C., Berger, M. C. and Hoehn, J. P. (1988), 'New estimates of quality of life in urban areas', American Economic Review 78(1), 89-106.

Borjas, G. J. (1995), 'Ethnicity, neighborhoods and human-capital externalities', American Economic Review 85(3), 365-389.

Borjas, G. J., Bronars, S. G. and Trejo, S. (1992), 'Self-selection and internal migration in the united states', Journal of Urban Economics 32, 159-185.

Bound, J. and Holzer, H. J. (1996), 'Demand shifts, population adjustments, and labor market outcomes during the 1980s', NBER Working Papers $\mathbf{5 6 8 5}$.

Edmond, J. B. (1978), The Magnificent Charter: The Origin and Role of the Morrill Land-Grant Colleges and Universities, Exposition Press.

Freeman, R. B. (1986), The demand for education, in O. Ashenfelter and R. Layard, eds, 'Handbook of Labor Economics', North Holland.

Friedman, M. (1962), Capitalism and Freedom, University of Chicago Press.

Glaeser, E. L. (1997), 'Learning in cities', mimeographed .

Glaeser, E. L., Scheinkman, J. A. and Shleifer, A. (1995), 'Economic growth in a cross-section of cities', Journal of Monetary Economics 36(1).

Greenstone, M. (1998), 'The wage consequences of enclave residence: Evidence from the 1990 and 1980 censuses', Manuscript, UC Berkeley .

Griliches, Z. (1979), 'Issues in assessing the contribution of r\&d to productivity growth', Bell Journal of Economics 10, 92-116.

Heckman, J. J. (2000), 'Policies to foster human capital', Research in Economics 54, 71-74.

Heckman, J. J. and Honore', B. E. (1990), 'The empirical content of the roy model', Econometrica 58(5), 1121-1149.

Heckman, J. J. and Sedlacek, G. L. (1985), 'Heterogeneity, aggregation, and market wage functions: An empirical model of self-selection in the labor market', Journal of Political Economy 93(6), 1077-1125.

Heckman, J. J. and Sedlacek, G. L. (1990), 'Self-selection and the distribution of hourly wages', Journal of Labor Economics 8(1), S329-63.

Heckman, J., Layne-Farrar, A. and Todd, P. (1996), 'Human capital pricing equations with an application to estimating the effect of schooling quality on earnings', The Review of Economics and Statistics 78(4), 562-610.

Jaeger, D. A. (1997), 'Reconciling the old and new census bureau education questions: Recomendation for researchers', Journal of Business and Economics Statistics 15(2), 300-308. 
Jovanovic, B. and Rob, R. (1989), 'The growth and diffusion of knowledge', Review of Economic Studies 56(4), 569-582.

Katz, L. F. and Murphy, K. M. (1992), 'Changes in relative wages, 1963-1987: Supply and demand factors', The Quarterly Journal of Economics 107, 35-78.

Kominsky and Siegel (1994), 'Measuring educational attainment in the cps', Population Division, US Bureau of Census .

Krueger, A. B. and Lindahl, M. (1998), 'Education for growth in sweden and the world', Industrial Relation Section Working Paper, Princeton.

Lucas, R. E. (1988), 'On the mechanics of economic development', Journal of Monetary Economics 22, 342.

MaCurdy, T., Mroz, T. and Gritz, R. M. (1998), 'An evaluation of the national longitudinal survey of youth', The Journal of Human Resources 33(2), 345-436.

Marshall, A. (1890), Principles of Economics, Macmillan.

Nervis, A. (1962), The State Universities and Democracy, University of Illinois Press.

Rauch, J. E. (1993), 'Productivity gains from geographic concentration of human capital: Evidence from the cities', Journal of Urban Economics 34, 380-400.

Roback, J. (1982), 'Wages, rents and the quality of life', Journal of Political Economy 90(6), 1257-1278.

Roback, J. (1988), 'Wages, rents and amenities: Differences among workers and regions', Economic Inquiry $\mathbf{2 6}(1), 23-41$.

Sacerdote, B. (2000), 'Peer effects with random assignment: Results for dartmouth roommates', Quarterly Journal of Economics 116, 681-704.

Stinebrickner, T. and Stinebrickner, R. (1999), 'Peer effects among students from disadvantaged backgrounds', mimeo .

Topel, R. (1999), Labor market and economic growth, in O. Ashenfelter and D. Card, eds, 'The Handbook of Labor Economics', North-Holland, Amsterdam.

Williams, R. L. (1991), The Origins of Federal Support for Higher Education, The Pennsylvania State University Press.

Zimmerman, D. (2002), 'Peer effects in academic outcomes: Evidence from a natural experiment', Review of Economics and Statistics. 


\section{Data Appendix}

National Longitudinal Survey of Youths: A special, confidential, version of the NLSY, where MSA of residence is identified, is used. I thank the Bureau of Labor Statistics for making this version available. I restrict the sample to the 9763 young men and women included in the 'cross-sectional sample' and the supplemental samples of Hispanics and Blacks. Following MaCurdy, Mroz and Gritz (1998) I exclude the supplemental sample covering economically disadvantaged whites — discontinued in 1991—and the military — discontinued in 1983. I use an unbalanced panel covering the years 1979-1994, excluding individuals who are 22 or younger. The maximum age is 37 . There are a total of 44,891 observations with non-missing values for all the relevant variables. The number of observations lost due to item nonresponse is 27,872 . The wage definition used is "hourly rate of pay in the current/most recent job". Not all MSAs identified in the Census are in the NLSY sample. The main discrepancy is that most New England observations in the NLSY have their MSA identifier missing, and they are not included in the analysis. Using the MSA code, individual-level data are matched to city-level college share from the Censuses. Data on the share of college educated workers are available from the Censuses only for 1980 and 1990. I therefore interpolate the Census estimates for all years from 1979 to 1994. An alternative would have been to use estimates obtained yearly from the Current Population Survey. Given the smaller sample size of the CPS, estimates of college share obtained by interpolating Census data turned out to be more precise than estimates obtained from CPS. ${ }^{39}$

Census: I use individual data from the 1970, 1980 and 1990 Census. For 1980 and 1990, data are from the $5 \%$ sample. The labor market information refers to 1979 and 1989. I first randomly select one in two observations, for computational ease. I then assign individuals a metropolitan area on the basis of two geographical identifiers, Public Use Microdata Areas (PUMAs) and metropolitan area codes. The finest geographic unit identified in the 5\% samples are PUMAs, which are arbitrary geographic divisions that contain no less than 100,000 people. Most individuals who live in a metropolitan area are also assigned a metropolitan area identifier (i.e. a MSA or CMSA or SMSA code). However, some PUMAs straddle

\footnotetext{
${ }^{39}$ The number of observations per city in the Census ranges from 935 to 99,371 . The number of observations per city in the CPS ranges from 36 to 4950. A regression of college share in 201 U.S. cities in 1990 obtained from the CPS against the one obtained from the Census yields a slope equal $1.06(0.06)$, not significantly different from one. The intercept is -1.48 (0.90), suggesting that there may be a systematic difference in measurement of education in the two surveys. The regression of Census estimates on CPS estimates yields an intercept equal 6.98 (0.39)and a slope equal $0.48(0.03)$.
} 
the boundary of one or more MSAs and in these 'mixed' PUMAs an MSA code is not assigned. These 'mixed' PUMAs are assigned a MSA code on the basis of the County Group Equivalency files. ${ }^{40}$ If over $50 \%$ of the PUMA population is attributable to a single MSA, I then assign all individuals in that PUMA to the majority MSA. The computer code for this assignment is available on request. Since the MSA definition was changed after the 1980 Census, I redefine 1990 SMSAs to match the 1980 boundaries. The County Group Equivalency files are used to identify PUMAs that contain the affected counties in the 1990 Census. ${ }^{41} 282$ MSAs are identified in 1980 and 1990. I use total annual earnings information together with data on weeks worked and hours per week over the year to construct an hourly wage measure and a simple indicator for employment status based on reporting positive earnings and hours. For those employed, I restrict attention to men and women between the ages of 25 and 70 , with non negative potential labor market experience. Individual are coded as employed if they report positive earnings, including wage and salary and/or self-employment earnings, and positive weeks of work and positive usual hours per week. Workers employed in agriculture or in the military are excluded. Wage rates less than $\$ 3.00$ per hour or greater than $\$ 60$ per hour are set to missing. Years of education are assigned to education codes used in 1990 Census following Table 1 in Kominsky and Siegel (1994). MSA size in 1990 ranges from 935 to 99,371 observations. The average size is 7288.8 . MSA size in 1980 ranges from 667 to 94,343 observations. The average size is 6355.8 .

Data from the 1970 Census are used only to estimate age structures needed for one of the instrumental variables. I use the $15 \%$ form state sample. The sample universe consist of all individuals residing in one of the MSAs. The finest geographical identifier in the 1970 Census is the county group code. The 1970 county group code is matched to the 1980 MSA code using information in the Census Bureau publication Geographic Identification Code Scheme (1983, 11-17). I follow the same procedure used by Altonji and Card (1991). The computer code used for the matching is available on request. Not all MSAs identified in 1980 and 1990 are identified in 1970. For those MSAs that are not identified in 1970, I use the state age distribution instead of the MSA age distribution.

\footnotetext{
${ }^{40}$ The methodology used to assign MSA codes and to match MSA across Censuses is identical to the one in Greenstone (1998), who generously provided the computer code.

${ }^{41}$ If the counties in question comprise more than half of the PUMAs population, all respondents are assigned to the pertinent MSA. If greater than $10 \%$ of an MSA 1990 population is affected by the boundary changes and is unrecoverable from the County Equivalency files, I drop the city from the analysis. Dayton and Springfield, Ohio are the only such cities.
} 
Table 1: Summary Statistics

\begin{tabular}{lccc}
\hline & NLSY & \multicolumn{2}{c}{ Census } \\
\cline { 2 - 4 } & $1979-94$ & 1990 & 1980 \\
\hline INDIVIDUAL-LEVEL VARIABLES & & \\
Log Hourly Wage & 1.89 & 2.30 & 2.26 \\
& $(0.51)$ & $(0.70)$ & $(0.67)$ \\
Years of Education & 13.10 & 13.17 & 12.86 \\
& $(2.36)$ & $(2.78)$ & $(3.00)$ \\
Years of Experience & 9.06 & 19.25 & 19.14 \\
& $(3.96)$ & $(12.7)$ & $(13.83)$ \\
Female & 0.48 & 0.47 & 0.44 \\
Black & 0.29 & 0.10 & 0.11 \\
Hispanic & 0.21 & 0.09 & 0.06 \\
U.S. Citizen & 0.95 & 0.94 & 0.96 \\
Work in Manufacturing & 0.18 & 0.18 & 0.24 \\
& & & \\
CITY-LEVEL VARIABLES & & & \\
Share of College Graduates & 0.24 & 0.25 & 0.21 \\
& $(0.05)$ & $(0.06)$ & $(0.05)$ \\
Unemployment Rate & 6.62 & 5.17 & 5.97 \\
& $(1.62)$ & $(1.05)$ & $(1.07)$ \\
Log Monthly Rent & 5.83 & 6.11 & 5.85 \\
& $(0.17)$ & $(0.18)$ & $(0.17)$ \\
& & & \\
Cities & & & \\
Individuals (N) & 201 & 282 & 282 \\
N×T & 6791 & 1981985 & 1694678 \\
\hline
\end{tabular}

NOTES: Standard deviations of continuous variables are in parenthesis. 


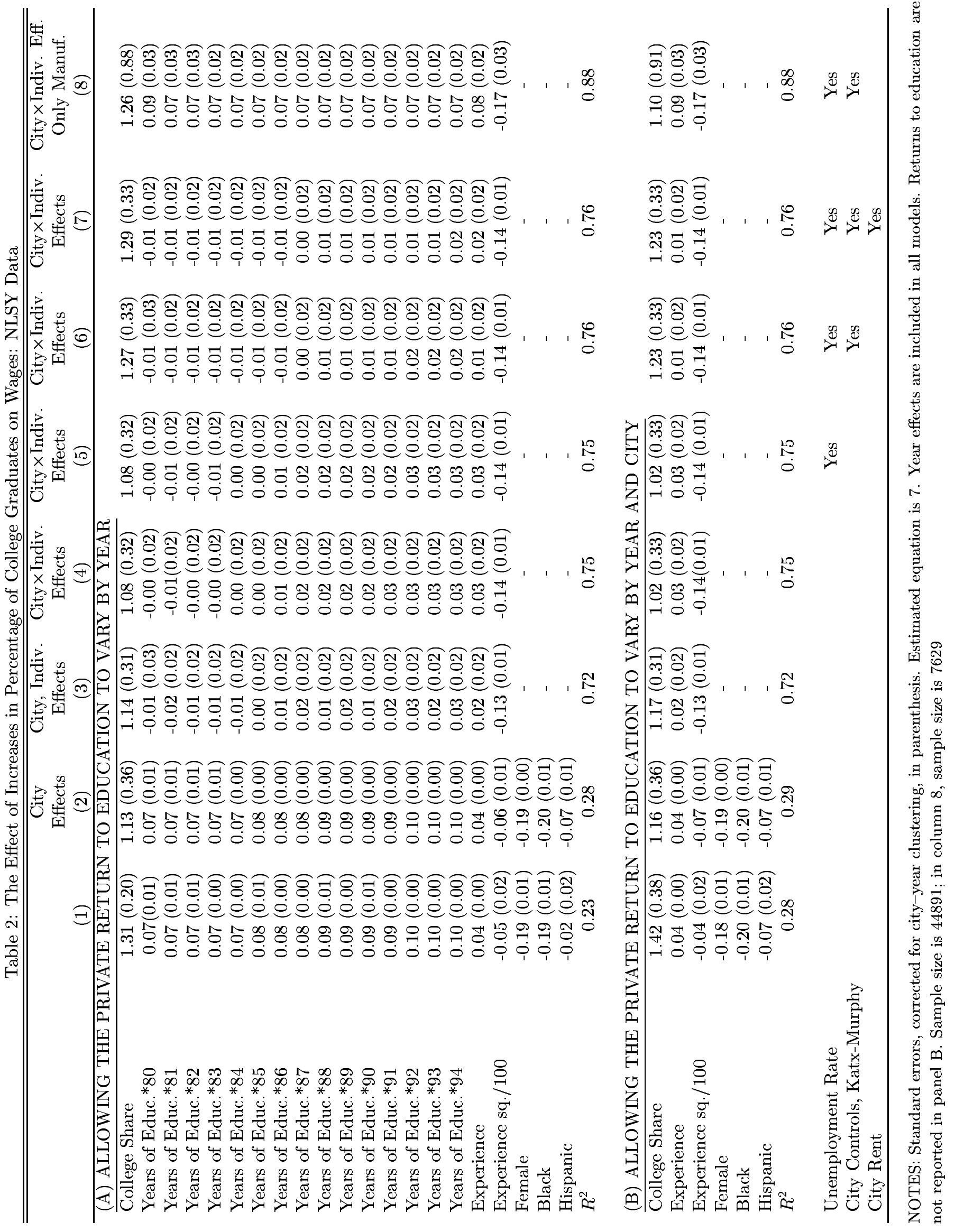


Table 3: Robustness Checks: NLSY

\begin{tabular}{lccc}
\hline \hline & $(1)$ & $(2)$ & Sample size \\
\hline (1) Basic specification & 1.27 & 1.29 & 44,891 \\
& $(0.33)$ & $(0.33)$ & \\
(2) Men & 1.29 & 1.31 & 44,891 \\
& $(0.36)$ & $(0.36)$ & \\
(3) Women & 1.24 & 1.22 & 44,891 \\
& $(0.37)$ & $(0.37)$ & \\
(4) College dummy & 1.24 & 1.25 & 44,891 \\
& $(0.33)$ & $(0.33)$ & \\
(5) Private return to educ. not linear & 1.25 & 1.26 & 44,891 \\
& $(0.34)$ & $(0.34)$ & \\
(6) Ret to AFQT vary by year & 1.77 & 1.75 & 36,510 \\
& $(0.36)$ & $(0.36)$ & \\
(7) Ret to AFQT vary by year and city & 1.70 & 1.68 & 36,510 \\
& $(0.36)$ & $(0.36)$ & \\
(8) Basic specification, AFQT non-missing & 1.72 & 1.70 & 36,510 \\
& $(0.35)$ & $(0.35)$ & \\
\hline
\end{tabular}

NOTES: Each entry is a separate regression. Entries are the coefficients of city college share.

(1) includes city $\times$ individual effects, individual characteristics, unemployment and other city controls, and the Katz and Murphy index. The return to schooling is allowed to vary by year. The base case in column 2 also includes rent. The estimates for the base case are from Table 2 (column 6 and 7 ).

(2) College share is interacted with dummy for men;

(3) College share is interacted with dummy for women;

(4) Dummy for college;

(5) Dummies for years of education;

(6) Return to education and AFQT vary by year

(7) Return to education AFQT vary by year and city

(8) Include only observations for which AFQT is non-missing 
Table 4: The Effect of Increases in Percentage of College Graduates on Wages: 1980 and 1990 Census Data

\begin{tabular}{lcccc}
\hline \hline & $\begin{array}{c}\text { OLS } \\
(1)\end{array}$ & $\begin{array}{c}\text { OLS } \\
(2)\end{array}$ & $\begin{array}{c}\text { OLS } \\
(3)\end{array}$ & $\begin{array}{c}\text { OLS } \\
(4)\end{array}$ \\
\hline FULL SAMPLE & & & & \\
College Share & 1.48 & 1.32 & 1.27 & 1.25 \\
$R^{2}$ & $(0.16)$ & $(0.11)$ & $(0.11)$ & $(0.11)$ \\
& 0.23 & 0.64 & 0.66 & 0.66 \\
WORKERS IN MANUFACTURING & & & & \\
College Share & 1.52 & 1.49 & 1.47 & 1.45 \\
$R^{2}$ & $(0.17)$ & $(0.14)$ & $(0.14)$ & $(0.14)$ \\
& 0.21 & 0.55 & 0.55 & 0.56 \\
City Effects & & & & \\
Unemployment and City Controls & Yes & Yes & Yes & Yes \\
Katz and Murphy Index & & & Yes & Yes \\
Rent & & & & Yes \\
\hline
\end{tabular}

NOTES: Each entry is a separate regression. Years effects are included in all models. Dependent variables are city-time specific intercepts in a regression of log wages on individual education, sex, race, Hispanic origin, US citizenship and a quadratic term in potential experience (see text). Standard errors in parentheses. 


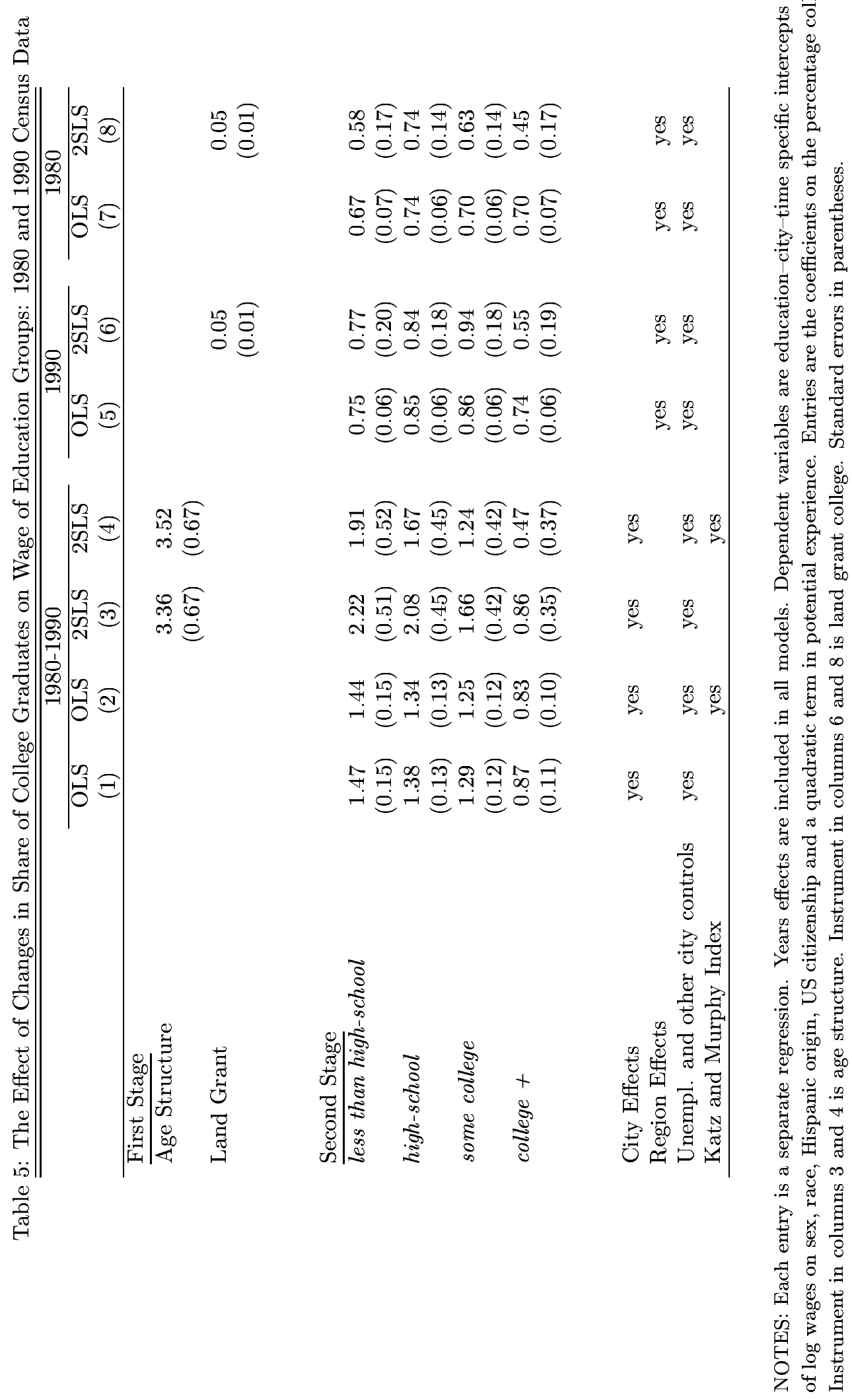


Table 6: Partial Correlation Between 1970 Demographic Structure and Changes in Population, Labor Force, Inflows of Domestic Workers, Inflow of Foreign Workers: Census Data

\begin{tabular}{lccccc}
\hline \hline & Change & Change & Change & Net Domestic & Internat. \\
& Populat. & Labor Force & Participat. Rate & Inflow & Inflow \\
& $1980-1990$ & $1980-1990$ & $1980-1990$ & $1980-1990$ & $1980-1990$ \\
& $(1)$ & $(2)$ & $(3)$ & $(4)$ & $(5)$ \\
\hline Share of Young, 1970 & 0 & 0 & 0 & 0 & - \\
Share of Middle-Aged, 1970 & 0 & 0 & 0 & 0 & + \\
Share of Old, 1970 & 0 & 0 & 0 & 0 & 0 \\
\hline
\end{tabular}

NOTES: Each entry is a separate regression. Entries in the first column are,+ 0 or - indicating whether the regression of percentage change in population on the share of a demographic group yields a positive, insignificant or negative coefficient. Entries in the remaining 4 columns are obtained similarly. Young individuals are aged 16-25; middle-age ones 26-60 and old ones 61-70.

Table 7: The Effect of the Presence of a Land Grant University on the Distribution of Education in City: 1990 Census Data

\begin{tabular}{|c|c|c|c|c|}
\hline & $\begin{array}{l}\text { College }+ \\
(1)\end{array}$ & $\begin{array}{c}\text { Some College } \\
(2)\end{array}$ & $\begin{array}{c}\text { High-School } \\
(3) \\
\end{array}$ & $\begin{array}{c}\text { High-School Drop Out } \\
(4)\end{array}$ \\
\hline Land-Grant & 0.05 & 0.002 & -0.02 & -0.03 \\
\hline & $(0.01)$ & $(0.004)$ & $(0.006)$ & $(0.005)$ \\
\hline$R^{2}$ & 0.39 & 0.64 & 0.62 & 0.57 \\
\hline Region Effects & Yes & Yes & Yes & Yes \\
\hline Unemployment and City Controls & Yes & Yes & Yes & Yes \\
\hline
\end{tabular}

NOTES: Each entry is a separate regression. The dependent variable is the percentage of individuals in city belonging to one of the four education groups. Standard errors in parenthesis. 
Table 8: Robustness Checks: 1980 and 1990 Census Data

\begin{tabular}{lcc}
\hline \hline & OLS & 2SLS \\
& $(1)$ & $(2)$ \\
\hline (1) Basic specification & 1.27 & 1.29 \\
& $(0.11)$ & $(0.38)$ \\
(2) Men & 1.23 & 1.04 \\
& $(0.13)$ & $(0.43)$ \\
(3) Women & 1.26 & 1.56 \\
& $(0.12)$ & $(0.41)$ \\
(4) College dummy & 1.16 & 1.12 \\
& $(0.14)$ & $(0.46)$ \\
(5) Private return to educ. not linear & 1.38 & 1.26 \\
& $(0.12)$ & $(0.40)$ \\
(6) IV includes only young, old indiv. & & 1.61 \\
& & $(0.56)$ \\
(7) IV includes only young indiv. & & 1.93 \\
& & $(0.68)$ \\
(8) MSA of Work & 1.29 & 1.50 \\
& $(0.13)$ & $(0.46)$ \\
(9) Industry dummies & 1.27 & 1.39 \\
& $(0.11)$ & $(0.37)$ \\
(10) Occupation dummies & 1.21 & 1.34 \\
& $(0.11)$ & $(0.38)$ \\
(11) College town dummy & 1.28 & 1.42 \\
& $(0.13)$ & $(0.42)$ \\
(12) City size & 1.29 & 1.26 \\
& $(0.12)$ & $(0.30)$ \\
(13) LAD & 1.62 & \\
& $(0.17)$ & \\
\hline & & \\
& &
\end{tabular}

NOTES: Each entry is a separate regression. Entries are the coefficients of city college share.

(1) The base case includes city effects, unemployment and other city controls, and the Katz and Murphy index. The OLS estimate for the base case is from Table 4 (column 3 ).

(2) Coefficient for men;

(3) Coefficient for women;

(4) Dummy for college;

(5) Dummies for years of education;

(6) Instrument is based only on variation in age groups $<35$ or $>55$;

(7) Instrument is based only on variation in age groups $<35$;

(8) Observations are assigned to MSA of work, not residence;

(9) 29 industry dummies are included;

(10) 4 occupation dummies are included;

(11) A college town dummy is included;

(12) City size is included;

(13) Median regression. 
Table 9: The Effect of Changes in Share of Workers with Graduate Degrees, College Degrees and Highschool Degrees on Wage of Education Groups: 1980 and 1990 Census Data

\begin{tabular}{lccc}
\hline \hline & $\begin{array}{c}\text { Share with } \\
\text { Graduate Degree }\end{array}$ & $\begin{array}{c}\text { Share with } \\
\text { College Degree }\end{array}$ & $\begin{array}{c}\text { Share with } \\
\text { High-School Degree }\end{array}$ \\
& $(1)$ & $(2)$ & $(3)$ \\
\hline less than high-school & 2.74 & 1.24 & 0.31 \\
high-school & $(0.31)$ & $(0.26)$ & $(0.16)$ \\
& 2.18 & 1.41 & 0.11 \\
some college & $(0.26)$ & $(0.20)$ & $(0.13)$ \\
& 1.89 & 1.40 & 0.23 \\
college & $(0.25)$ & $(0.19)$ & $(0.13)$ \\
& 1.08 & 1.18 & 0.08 \\
graduate school & $(0.25)$ & $(0.18)$ & $(0.12)$ \\
& 0.76 & 1.24 & -0.10 \\
& $(0.34)$ & $(0.25)$ & $(0.16)$ \\
City Effects & & & \\
Unempl. and other city controls & & & yes \\
Katz and Murphy Index & yes & yes & yes \\
\hline
\end{tabular}

NOTES: Years effects are included in all models. Dependent variables are education-city-time specific intercepts in a regression of log wages on sex, race, Hispanic origin, US citizenship and a quadratic term in potential experience. Entries in column 1 are the coefficients on the percentage with graduate degrees. Entries in column 2 are the coefficients on the percentage with college degrees. Entries in column 3 are the coefficients on the percentage with high-school degrees. Standard errors in parentheses. 

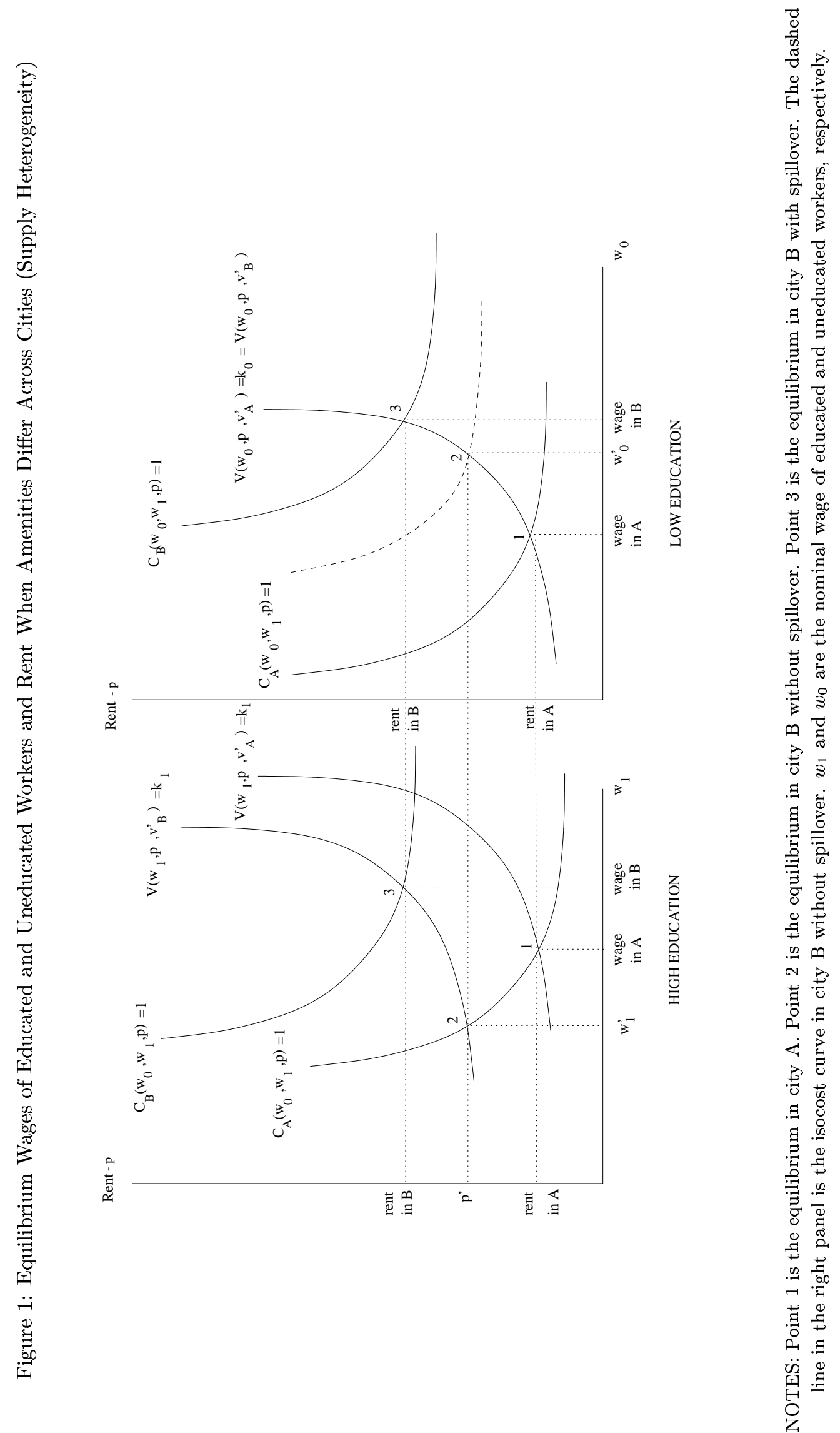

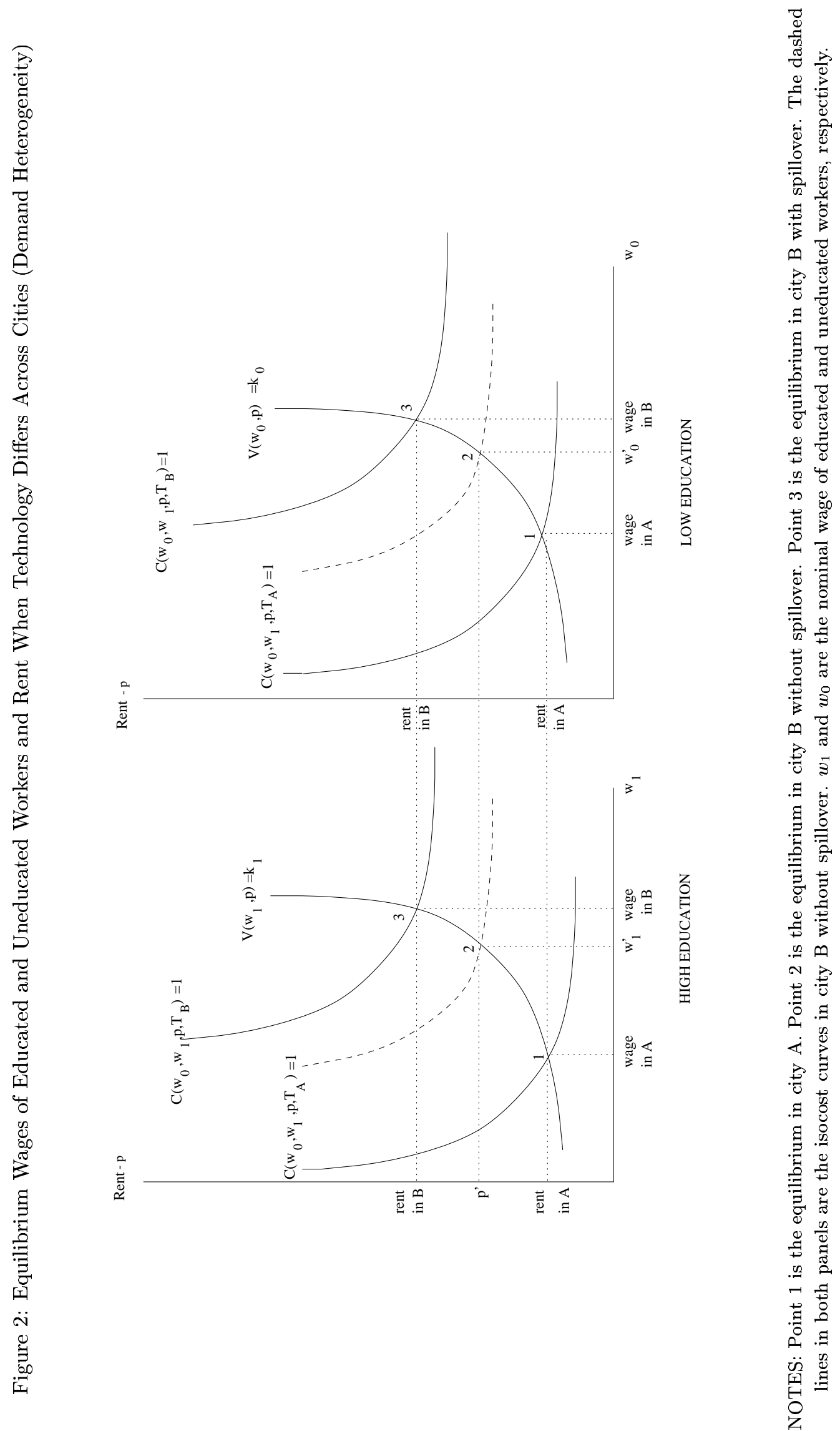
Figure 3: Correlation Between Regression-Adjusted Average Wage in City and Percentage of College Graduates in City.

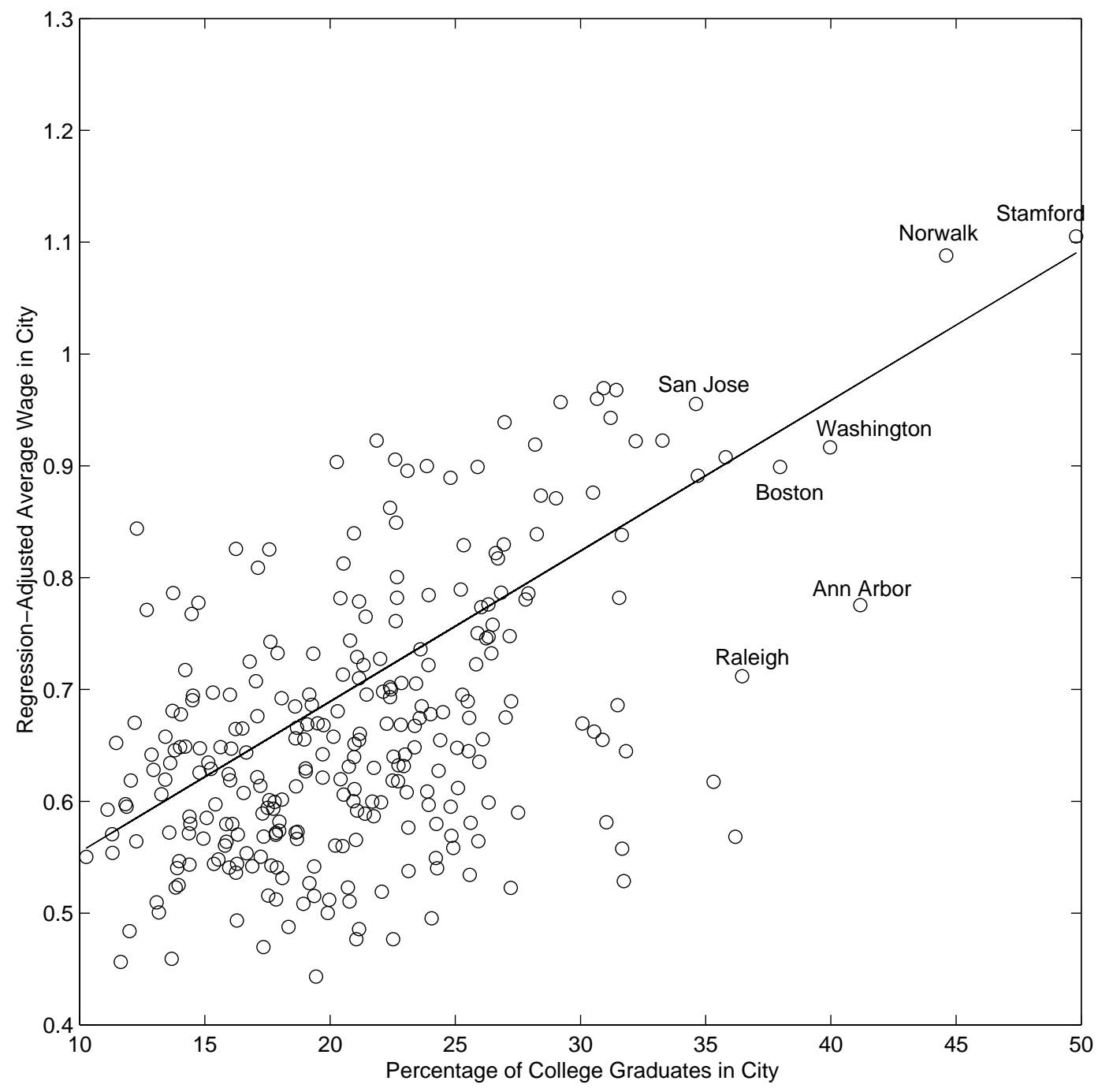

NOTES: Regression-adjusted average wage is obtained by conditioning on individual education, gender, race, Hispanic origin, U.S. citizenship and work experience. Weighted OLS fit superimposed. Source: 1990 Census 
Figure 4: Difference in Distribution of Schooling Between Cities With and Without a Land Grant College.

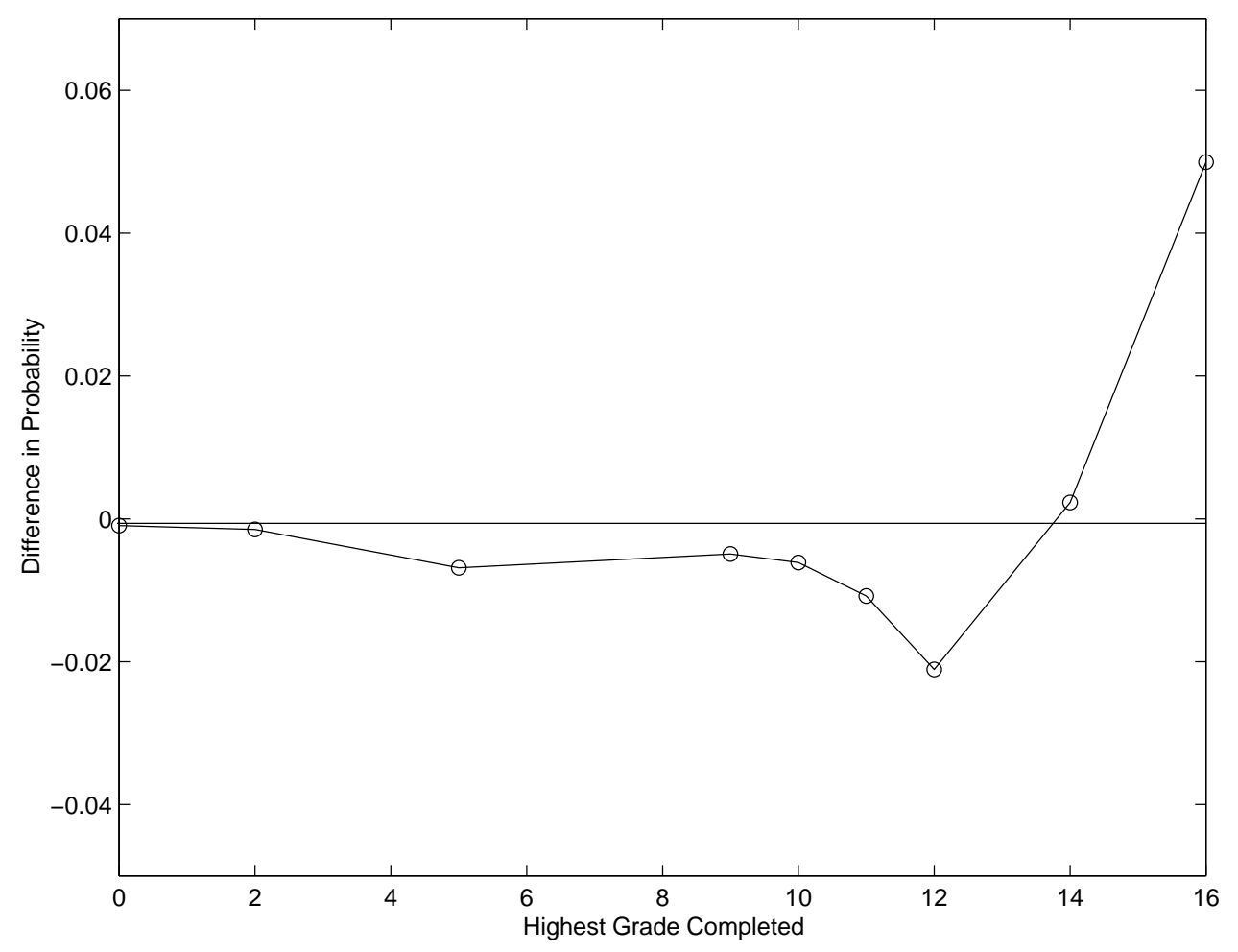

Source 1990 Census 